NBER WORKING PAPER SERIES

\title{
HUMAN CAPITAL SPILLOVERS IN MANUFACTURING: EVIDENCE FROM PLANT-LEVEL PRODUCTION FUNCTIONS
}

\author{
Enrico Moretti \\ Working Paper 9316 \\ http://www.nber.org/papers/w9316 \\ NATIONAL BUREAU OF ECONOMIC RESEARCH \\ 1050 Massachusetts Avenue \\ Cambridge, MA 02138 \\ October 2002
}

I am indebted to Dan Ackerberg, Michael Ash, Sandy Black, David Card, Janet Currie, Robert Dekle, Paul Devereux, Joe Hotz, Phillip Leslie, David Levine, Darren Lubotsky, Marco Manacorda, Charles Mullin and seminar participants at Berkeley and USC for useful comments on this and previous drafts. The research in this paper was conducted while the author was a Census Bureau research associate at the California Census Research Data Center. Research results and conclusions expressed are those of the author and do not necessarily indicate concurrence by the Bureau of Census. This paper has been screened to ensure that no confidential data is revealed. A previous version of this paper circulated under the title: "Workers' Education, Externalities and Technology Adoption: Evidence From Plant-Level Production Functions", CLE Working Paper 21, November 1999. The views expressed herein are those of the authors and not necessarily those of the National Bureau of Economic Research.

(C) 2002 by Enrico Moretti. All rights reserved. Short sections of text, not to exceed two paragraphs, may be quoted without explicit permission provided that full credit, including (C) notice, is given to the source. 
Human Capital Spillovers in Manufacturing:

Evidence From Plant-Level Production Functions

Enrico Moretti

NBER Working Paper No. 9316

October 2002

JEL No. J0, I2, O4

\begin{abstract}
I assess the magnitude of human capital spillovers in US cities by estimating plant-level production functions. I use a unique firm-worker matched dataset, obtained by combining the Census of Manufacturers with the Census of Population. After controlling for a plant's own human capital, plant fixed effects, and industry-specific and state specific transitory shocks, I find that the output of plants located in cities that experience large increases in the share of college graduates rises more than the output of smaller plants located in cities that experience small increases in the share of college graduates. Several specification tests indicate that the estimated effect is unlikely to be completely spurious. First, within a city, spillovers between plants that rarely interact are zero, while spillovers between plants that often interact are significant. Second, density of physical capital in a city outside a plant has no effect on a plant's productivity. Third, most of the estimated spillover comes from high-tech plants. For low-tech plants, the spillover is virtually zero. The estimated productivity differences between cities with high and low levels of human capital match remarkably well differences in labor costs between cities and high and low level of human capital. Consistent with a model that includes both standard general equilibrium forces and spillovers, the productivity gains generated by human capital spillover are offset by increased labor costs.
\end{abstract}

\title{
Enrico Moretti
}

Department of Economics

UCLA

405 Hilgard Avenue

Los Angeles, CA 90095-1477

and NBER

moretti@ucla.edu 


\section{Introduction}

Human capital externalities may arise if the presence of educated workers makes other workers more productive. Marshall (1890) is among the first to recognize that social interactions among workers create learning opportunities that enhance productivity. Lucas (1988) argues that human capital externalities in the form of learning spillovers may be large enough to explain long-run income differences between rich and poor countries. In the typical learning model, individuals augment their human capital through pairwise meetings with more skilled neighbors during which they exchange ideas (Glaeser 1999, Jovanovic and Rob 1989).

Empirical evidence indicates that spillovers may be important in some hi-tech industries. For example, biotechnology firms are more productive if located near large research universities (Zucker, Darby and Brewer 1998). Patent citations are more likely to come from the same state or metropolitan area as the originating patent (Jaffe, Trajtenberg and Henderson 1993). Findings in Glaeser and Mare (2001) are consistent with a model where individuals acquire skills by interacting with one another, and dense urban areas increase the probability of interaction. ${ }^{1}$ Yet, despite significant policy implications, there is little systematic empirical evidence on the magnitude of human capital spillovers. Only recently have some authors attempted to estimate the size of spillovers from education by comparing the wages of otherwise similar individuals who work in cities or states with different average levels of education. ${ }^{2}$

In this paper, I take a more direct approach to the estimation of human capital externalities and focus on the productivity of manufacturing plants. The idea is quite simple. If externalities exist, we should see that plants located in cities with a high level of human capital can produce a greater output with the same inputs than otherwise similar plants located in cities with a low level of human capital. To test this hypothesis, I estimate plant level production functions using a unique firm-worker matched dataset, obtained by combining the Census of Manufacturers with the Census of Population.

For each plant and city, I define the overall level of human capital in the city by calculating the percentage of college educated workers in the city who work outside the plant. After controlling for a plant's own human capital, I find that the productivity of plants located in cities

\footnotetext{
${ }^{1}$ Glaeser, Scheinkman and Shleifer (1995) report that income per capita has grown faster in cities with high initial human capital in the post-war period.

${ }^{2}$ See, for example, Rauch (1993), Acemoglu and Angrist (1999), Ciccone and Peri (2002), Moretti (forthcoming).
} 
that experience increases in the overall level of human capital rises more than the productivity of otherwise similar plants located in cities where the overall level of human capital does not change. The key econometric issue in comparing the productivity of plants across metropolitan areas with different overall levels of human capital is the possible presence of unobserved factors that may raise productivity and attract a more educated labor force to a city. It is possible that more productive plants are located in cities with a better educated labor force for reasons independent of human capital spillovers.

A benefit of using longitudinal, plant-level data is that I can deal with some of the most relevant endogeneity and selectivity issues. ${ }^{3}$ By looking at changes over time, I correct for permanent unobserved characteristics of plants and cities that might bias a simpler cross-sectional specification. It is still possible that time-varying productivity shocks are correlated with changes in the overall level of human capital in an area. For example, if Southern states that have low level of productivity at the beginning of the period, catch up, and this modernization process in turn attracts a better educated labor force to the South, then the estimated spillover will be too large. To lessen any fear that overall college share is correlated with time-varying unobserved factors, I control for state $\times$ industry $\times$ year effects. Identification comes by comparing changes over time in the productivity of plants that are in the same state and industry, but in different cities.

Even after controlling for plant fixed effects, industry-specific transitory shocks and state specific transitory shocks, it is still possible that part of the correlation between plants' productivity and aggregate human capital reflects changes in unobserved characteristics of cities. I can not completely rule out this possibility. But I provide four specification checks to further investigate the validity of my assumptions.

First, I test whether the stock of physical capital in a city outside a plant is associated with increased productivity in the plant. If my estimate of human capital spillovers are spurious, or if they can be explained by agglomeration effects other than human capital externalities, then I may find that more productive plants are located in areas with higher density of physical capital. On the contrary, if my estimates are capturing only human capital externalities, there is no reason why physical capital in a plant should be correlated with productivity in other plants. I find that the overall stock of physical capital in a city outside a plant has no effect on

\footnotetext{
${ }^{3}$ Henderson (2001) is the first to estimate externalities on productivity using longitudinal plant level data. Typically, other authors have used city-industry cross-sectional aggregate data.
} 
a plant's productivity.

Second, I test whether the magnitude of spillovers between industries depends on their level of interaction. If I found that spillovers between industries that hardly interact were as large as between industries that often interact, then that would indicate that my estimates of the spillover were contaminated by city-wide productivity shocks. I use input-output tables to measure interaction between industries. The input-output tables show how industries provide input to, and use output from, each other. According to this measure, manufacturing interacts more with "services" than with "finance and real estate" because it uses more inputs from "services" than from "finance and real estate". Using this definition, I find that, within a city, spillovers between plants that often interact are significant, while spillovers between plants that rarely interact are much smaller.

Third, I test whether human capital spillovers matter more for "knowledge intensive" productions. I expect that spillovers matter more for industries like computers, scientific equipment, bio-tech, or pharmaceutical than industries like cement, steel or lumber. Finding that human capital spillovers are more important for cement than for bio-tech or computers, would cast doubt on the estimates. I find that most of the estimated spillover comes from hi-tech plants. For low-tech plants, the spillover is virtually zero. When I stratify the sample by the fraction of employees who are college educated, I find that the spillover is larger the larger the fraction of college educated workers in the plant.

Finally, I test whether the magnitude of the spillover varies by multi-unit status. Henderson (2001) argues that single-unit establishments should be more sensitive to the level of human capital in the local environment than multi-unit establishments. Multi-unit establishments are part of larger corporations with plants in many cities and are less likely to be connected to their local environment. For example, it is likely that many decisions that affect the productivity of a General Motors' establishment in St. Louis are made in Detroit. On the contrary, all decisions that affect the productivity of a single-unit establishment in St. Louis are made in St. Louis. I find that the estimated spillover is large for single-unit establishments, and virtually zero for multi-unit establishments.

According to the most robust estimates, a one percent increase in the city college share is associated with a 0.5 percentage point increase in output. I assess the plausibility of this estimate by comparing it with the difference in labor costs between cities with high a low 
level of human capital. In equilibrium, if firms are really more productive in cities with high levels of human capital, we should observe that labor costs are also higher there (holding constant workers' characteristics). Otherwise, manufacturing firms would relocate from cities with low human capital to cities with high human capital. I find that the estimated productivity differences between cities with high human capital and low human capital are consistent with observed differences in wages of manufacturing workers. The productivity gains generated by human capital spillover are offset by increased labor costs.

Based on: (1) the robustness of the coefficients across specifications; (2) the four specification tests; and (3) the fact that the estimated spillover is consistent with observed wage differences across cities, I conclude that the estimated spillover is not completely spurious.

The remainder of the paper is organized as follows. In section 2, I present a simple general equilibrium framework with spillovers. In section 3, I describe the econometric specification adopted and I discuss the potential sources of bias. In Section 4, I describe the matched Census of Manufacturers-Census of Population dataset. Section 5 presents the empirical results. In section 6, I compare the magnitude of the estimated spillover with wage differences across cities. Concluding remarks are in section 7 .

\section{Equilibrium with Spillovers}

In this section I present a simple general equilibrium framework to show that an equilibrium exists when human capital spillovers are present. The model is adapted from a well known model by Roback (1982, 1988). The intuition is simple. Firms are more productive in cities with high overall level of human capital, because of spillovers. In equilibrium, firms are indifferent across cities because wages are higher in cities with a higher overall level of human capital, so that unit costs are the same everywhere. Workers are indifferent because housing prices are higher in cities with a higher overall level of human capital.

The model indicates that there are two ways to empirically measure human capital externalities: by comparing output of firms located in cities with high and low level of human capital; and by comparing wages of workers located in cities with high and low level of human capital. In this paper, I take the former approach. In section 6, I show that the estimated

productivity differences between cities with high and low levels of human capital are consistent 
with observed wage differences between cities with high and low levels of human capital.

Consider two cities and two types of labor, educated and uneducated workers. There are two types of goods, a composite good $y$-nationally traded - and land $h$-locally traded. Each city is a competitive economy that produces $y$ using a Cobb-Douglas technology: $y=$ $A L 1^{\alpha_{1}} L 2^{\alpha_{2}} K^{\beta}$, where $L 1$ and $L 2$ are the hours worked by skilled and unskilled workers, respectively and $\mathrm{K}$ is capital.

To introduce the possibility of human capital spillovers in the model, I allow the productivity of plants in a city to depend on the aggregate level of human capital in the city: $A=f(\bar{S})$. In the empirical part of the paper, for each firm and city, I measure $\bar{S}$ using the percentage of college educated workers in the city, outside the firm. In the absence of human capital spillovers from education, $\frac{\delta f}{\delta S}=0$. In this case, productivity of a firm increases if more skilled workers are employed in the firm, but holding constant the number skilled workers in the firm, increases in the share of educated workers in the city have no effect on productivity. On the other hand, if college share in a city generates positive human capital spillovers, a rise in college share raises productivity of all plants in the plant: $\frac{\delta f}{\delta S}>0$. Different explanations of human capital externalities have been proposed in the theoretical literature, and the model proposed here is consistent with most explanations. ${ }^{4}$

Workers maximize utility subject to a budget constraint by choosing quantities of the composite good and residential land. Workers and firms are perfectly mobile. Equilibrium is obtained when workers have equal utilities in all cities and firms have equal unit cost across cities. Because the composite good, $y$, is traded, its price is the same everywhere. Variation in the cost of living depends only on variation in cost of land, $p$, which is the same for all workers in a city.

\footnotetext{
${ }^{4}$ Marshall (1890) is often quoted as arguing that social interactions among workers in the same industry and location create learning opportunities that enhance productivity. More recently, an influential paper by Lucas (1988) focuses on the benefits associated with urban areas that come from firms acquiring ideas from their neighbors. In Lucas words: "We know that there are group interactions that are central to individual productivity. [...] We know that this kind of external effect is common to all the arts and sciences." The external effect of human capital, Lucas adds, in not limited to art and science: "Much of economic life is creative in much the same way as is art and science.". Lucas argues that long-run income differences across countries can be explained by human capital externalities in the form of learning spillovers. In subsequent models of learning, individuals augment their human capital through exchanges of ideas in meetings with more skilled neighbors (Glaeser 1999, Jovanovic and Rob 1989). Acemoglu (1996) proposes an alternative model where human capital externalities arise even without learning externalities. The goal of this paper is to test whether spillovers are empirically relevant. Testing which of the explanations proposed in the theoretical literature is valid, is beyond the scope of this paper.
} 
The equilibrium for the simple case of only two cities, A and B, is described in Figure 1. The upward sloping lines in each panel represent indifference curves for the two education groups. Indirect utility of skilled and unskilled workers - $V_{1}\left(w_{1}, p\right)$ and $V_{2}\left(w_{2}, p\right)$, respectivelyis a function of nominal wages and cost of land. The downward sloping lines show combinations of wages and rents which hold constant firms' unit costs: $C\left(w_{1}, w_{2}, p, r, \bar{S}\right)=1$, where $r$ is the price of capital, which is assumed to be constant across cities. If human capital externalities exist, $\bar{S}$ enters the cost function. In cities with more human capital, firms can produce more output with the same amount of labor and capital, or the same output with less inputs.

In equilibrium, utility of workers is equalized across locations: $V_{1}\left(w_{1}, p\right)=k_{1}$ and $V_{2}\left(w_{2}, p\right)=$ $k_{2}$ for educated and uneducated workers, respectively. A zero-profit condition for the firm assures that production must take place along the downward sloping curve. Thus the model has three equations (unit cost and indirect utility for each skill group) in three unknowns $\left(w_{1}\right.$, $w_{2}$ and $p$ ). Point 1 in the left panel of Figure 1 represents the equilibrium combination of wage of educated workers and cost of land in city A. Point 1 in the right panel represents the same combination for uneducated workers. ${ }^{5}$

Consider what happens if the share of college educated workers is higher in city B than in city A. For example, suppose that, because of technological differences, skilled workers are particularly productive in city B and demand for them is high. Skilled workers move to B, attracted by higher wages. Even without spillovers, wages are higher. Point 2 represents the equilibrium in city $B$ if there are no spillovers. ${ }^{6}$ If the spillover exists, then the isocost curve shifts further to the right. The magnitude of the spillover is the distance from 2 to 3 .

In equilibrium, firms in city B are more productive than firms in city A. Since firms are free to relocate from A to B, why is productivity not driven to equality? Wages (and rent) are higher in city $\mathrm{B}$, making firms indifferent between cities. If the cost of land is not very important for firms - as it is the case for manufacturing firms analyzed in the empirical part - the increased productivity in B relatively to A should be offset by increased labor costs in B relatively to A. I will come back to this point in Section 6, where I compare my estimates of the difference in productivity between cities with high and low human capital with existing differences in labor

\footnotetext{
${ }^{5}$ I follow Roback (1988) and take the level of utility $k_{1}$ and $k_{2}$ as parameters for simplicity. Closure of the model would require that the level of utility is made endogenous. This would complicate the model, without making it more insightful.

${ }^{6}$ The wage of educated workers is higher in B because they are more productive. The wage of uneducated workers is higher because of complementarity (imperfect substitution).
} 
costs.

\section{Econometric Framework}

\subsection{Biases Resulting from Unobserved Heterogeneity}

The model in Section 2 indicates that, if human capital spillovers exist, firms in cities with higher overall level of human capital $\bar{S}$ can produce the same amount of output with less inputs, or more output with the same inputs. This paper estimates production functions to assess the magnitude of the productivity gains that are generated by human capital spillovers. I begin in this section by discussing the identification issues that arise in estimating human capital spillovers using production functions. In section 3.2, I describe how I address these identification issues.

The fundamental problem in estimating spillovers is the presence of unobservable factors that affect productivity and are correlated with the overall level of human capital across cities. It is possible that more productive firms are located in areas with a higher level of human capital, for reasons independent of human capital externalities. To see what this implies, I now introduce heterogeneity in the simple model described in the previous section. As in Section 2, I assume that technology can be described by the following Cobb-Douglas production function:

$$
y_{p j c t}=A_{p j c t} L 1_{p j c t}^{\alpha_{1 j}} L 2_{p j c t}^{\alpha_{2 j}} K_{p j c t}^{\beta_{j}}
$$

where $y_{p j c t}$ is output of plant $p$, belonging to industry $j$, in city $c$, and year $t ; j$ indexes 3 -digit industries; $L 1_{p j c t}$ is the number of hours worked by skilled workers in the plant ; $L 2_{p j c t}$ is the number of hours worked by unskilled workers; $K_{p j c t}$ is capital. As in Section 2, I assume that $A_{p j c t}$ is a function of college share outside the firm in the same city. But unlike Section 2, I also allow for unobservable productivity shocks:

$$
\ln A_{p j c t}=\gamma \bar{S}_{-j c t}+\epsilon_{p}+\epsilon_{j}+\epsilon_{t}+\epsilon_{c}+\epsilon_{j t}+\epsilon_{c t}+\epsilon_{s t}+\epsilon_{p j c t}
$$

where $\bar{S}_{-j c t}$ is the share of college graduates among all manufacturing workers in city $c$ with the exception of workers in industry $j$; and the $\epsilon$ 's are unobserved productivity shocks at the plant, city, state, industry and year level ( $s$ indexes the state where city $c$ is located). Equation 
2 captures only spillovers that occur within a city across 3-digit industries. It does not capture spillovers that occur within a plant, since the focus of the paper is on externalities between plants. (Spillovers within a plant are likely to be internalized.) Nor does it capture spillovers that occur between plants in the same 3-digit industry, because this is not empirically feasible due to data limitations. To the extent that spillovers between plants in the same 3-digit industry are large, estimates of $\gamma$ are to be interpreted as a lower bound on the magnitude of total spillovers. ${ }^{7}$ For now, equation 2 captures only spillovers generated within manufacturing. Later, I generalize this assumption and I include college share in manufacturing as well as in all other industries.

In logs the production function becomes

$$
\ln y_{p j c t}=\gamma \bar{S}_{-j c t}+\alpha_{1 j} \ln L 1_{p j c t}+\alpha_{2 j} \ln L 2_{p j c t}+\beta_{j} \ln K_{p j c t}+\epsilon_{p}+\epsilon_{j}+\epsilon_{t}+\epsilon_{c}+\epsilon_{j t}+\epsilon_{c t}+\epsilon_{s t}+\epsilon_{p j c t}
$$

The coefficient of interest in equation 3 is $\gamma$, the external effect of education on productivity. If $\gamma=0$, the model reduces to a standard production function without externalities. The main concern in estimating $\gamma$ is the presence of unobservable productivity shocks that are potentially correlated with college share. A positive correlation between the $\epsilon$ 's and $\bar{S}_{-j c t}$ would result in overestimates of $\gamma$.

For example, $\epsilon_{p}$ captures unmeasured plant characteristics that do not change over time, such as the quality of machines, patents, quality of management, and the culture within the firm (to the extent that they are permanent.) A positive $\epsilon_{p}$ therefore indicates that the productivity of plant $p$ is permanently higher than at similar plants. If plants with a positive $\epsilon_{p}$ tend to be located in cities with a high overall level of human capital, then OLS estimates of equation 3 overestimate $\gamma^{8}$ Similarly, the term $\epsilon_{c}$ captures permanent city characteristics that make some cities more productive than others. These may include the public infrastructure (ports, highways, or airports), weather conditions, the presence of a research universities, and

\footnotetext{
${ }^{7}$ In theory, a more general specification would allow for spillovers between plants in the same 3-digit industry. This alternative specification would replace $\bar{S}_{-j c t}$ in equation 2 with $\bar{S}_{-p j c t}$, which is the college share in all manufacturing plants in city $c$ with the exception of plant $p$. As it will be clear below, this is not feasible because of data limitations. Note, however, that the 3-digit industry classification is very detailed, and in many cases there is only one plant per city in each 3-digit industry, so that $\bar{S}_{-j c t}=\bar{S}_{-p j c t}$.

${ }^{8} \mathrm{~A}$ similar point is made graphically in Figure 1. The true spillover is the difference in productivity between a plant in point 3 and a plant in point 2. But if the technology that raises productivity of educated workers in city $\mathrm{B}$ relative to city $\mathrm{A}$ is unobserved, the estimated spillover is the difference in productivity between a plant in point 3 and a plant in point 1 , which overestimates the true spillover.
} 
efficiency of local authorities. If city with a well educated labor force tend to have good public infrastructure, good weather or efficient local authorities, estimates of $\gamma$ overestimate the true spillover. ${ }^{9}$

Turning to the interactions, $\epsilon_{c t}$ is a time-specific shock that affects productivity of all plants in city $\mathrm{c}$, irrespective of the industry. Examples include the opening of an airport, the construction of a rail link or a freeway, or improvements in the policies of local administrators. These city-wide, time-varying shocks can alter the overall level of human capital in the city by attracting better educated workers, and therefore are potentially correlated with overall college share, $\bar{S}_{-j c t}$.

Similarly, state and time specific shocks, $\epsilon_{s t}$, could also be sources of bias. For example, it is possible that some parts of the South, where productivity was low at the beginning of the 1980s, caught up with the rest of the country during the 1980s, and that this modernization process attracted a better educated labor force. Alternatively, it is possible that states that invested more in public infrastructures during the 1980s also spent more on public education and training, thus raising both human capital and firms' productivity. Again, the presence of this type of state level shocks would bias estimates of $\gamma$ upward.

The term $\epsilon_{j t}$ captures industry and year specific shocks. A positive $\epsilon_{j t}$ could indicate the introduction of an industry-specific new technology that raises productivity. If industries that are quicker to adopt new technologies tend to be concentrated in areas with high aggregate human capital, estimates of $\gamma$ will be upward biased. Alternatively, $\epsilon_{j t}$ may indicate an increase in the demand for output produced by industry $j$, since output is measured in monetary terms.

\subsection{Identification of Spillovers in the Presence of Heterogeneity}

A major advantage of using a longitudinal plant-level dataset is that the richness of the data allows me to account for some unobservable factors that may affect both productivity and overall college share. Specifically, I estimate a production function that includes plant fixed effects $\left(d_{p}\right)$, industry $\times$ year effects $\left(d_{j t}\right)$ and state $\times$ year effects $\left(d_{s t}\right)$ :

$$
\ln y_{p j c s t}=\gamma \bar{S}_{-j c t}+\alpha_{1 j} \ln L 1_{p j c t}+\alpha_{2 j} \ln L 2_{p j c t}+\beta_{j} \ln K_{p j c t}+d_{p}+d_{j t}+d_{s t}+\epsilon_{c t}+\epsilon_{p j c t}
$$

\footnotetext{
${ }^{9}$ The term $\epsilon_{j}$ captures fixed industry characteristics that make some industries more productive than others; $\epsilon_{t}$ captures general trends in technology that affect all plants as well as variation in productivity over the business cycle. I ignore $\epsilon_{j c}$ and $\epsilon_{p t}$ for simplicity.
} 
Equation 4 is the basis of the empirical analysis in this paper. The relative importance of capital and labor is allowed to vary across industries, since the technological parameters $\alpha_{1 j}$, $\alpha_{2 j}$ and $\beta_{j}$ vary across industries. Plant fixed effects fully absorb permanent heterogeneity at the plant, city, and industry level $\left(\epsilon_{p}, \epsilon_{c}\right.$ and $\left.\epsilon_{j}\right)$. Because of the inclusion of plant fixed effects, identification is based on changes over time in overall college share. The inclusion of state $\times$ year effects absorb state specific transitory shocks. This specification yields consistent estimates if time-varying productivity shocks are similar across cities in the same state. Industry $\times$ year absorb any industry specific time-varying shocks. In some models, I include industry $\times$ state $\times$ year effects $\left(d_{j s t}\right)$. In these models, identification comes from changes over time within a state and industry.

The main source of heterogeneity that is not controlled for in equation 4 is the time-varying, city specific shock: $\epsilon_{c t}$. The possible correlation between $\epsilon_{c t}$ and college share in all other industries in the same city, $\bar{S}_{-j c t}$ is a concern. (Note that correlation between $\epsilon_{c t}$ and college share in the same industry, $\bar{S}_{j c t}$, would not results in biased estimates.) In theory one might think to absorb $\epsilon_{c t}$ with city $\times$ year effects. In practice, though, this is not feasible, because such model would be almost completely saturated. ${ }^{10}$

To try to account for time-varying city specific heterogeneity, in some specifications I include observable city characteristics such as city population, unemployment rate, and racial composition. For example, controlling for changes in city size is particularly important, because college graduates are more likely to be found in large cities. If outsourcing increases with the size of the city, return to specialization may benefit plants in larger cities. Of course, controlling for observable city characteristics is no guarantee that unobservable characteristics are also controlled for.

In sum, I control for many sources of unobserved heterogeneity, but I can not completely rule out the possibility of spurious correlation. The key identifying assumption is that, after controlling for plant effects, industry $\times$ state $\times$ year effects and city time-varying observable characteristics, unobserved city-wide shocks, $\epsilon_{c t}$, and overall college share in all other industries, $\bar{S}_{-j c t}$, are uncorrelated. What are examples of situations that would violate this assumption? The possibility that plants with better machines or better management tend to locate in areas

\footnotetext{
${ }^{10}$ Most of the variation in $\bar{S}_{-j c t}$ is at the city $\times$ year level, since $\bar{S}_{-j c t}$ differs from college share in a city and year only because it does not include one 3 -digit industry. Including city $\times$ year dummies would virtually eliminate $\bar{S}_{-j c t}$ from the regression.
} 
with high college share, does not constitute a problem here, as plant fixed effects absorb plant and city specific heterogeneity. Similarly, shocks that affect local economies because of their industrial composition, are controlled for. ${ }^{11}$

In order for a shock to induce spurious correlation in equation 4 , the shock needs to be city-wide and time-varying. One example of such a shock could be the opening of an airport or a freeway. If the new infrastructure raises the productivity of all existing manufacturing plants in the city, and at the same time it attracts more college graduates to the city, estimates of $\gamma$ will be too large. Another example is changes in the quality of workers. It is in theory possible that workers of higher ability locate in cities that experience larger increases in college share. I discuss this issue in greater length in Section 5.6, providing evidence that heterogeneity in workers quality is not in fact driving my results.

A final concern is that capital and labor inputs should in theory be treated as endogenous. Unlike the usual case of estimation of production functions, here the focus is not on estimating the coefficients on capital and labor, but it is on estimating $\gamma$. Endogeneity of capital and labor is an issue only to the extent that it results in biased estimates of $\gamma$. Through the paper, I assume that, after controlling for plant effects, industry $\times$ year effects and state $\times$ year effects, endogeneity of capital and labor does not significantly bias estimates of $\gamma$.

This assumption is correct if changes over time in capital and labor at a plant are mostly driven by shocks that are common to all the plants in the same industry and state. This would be the case, for example, if all car plants in Ohio vary their capital and labor inputs by a similar amount in the period under consideration. The assumption is also correct if there is variation across plants in changes over time in capital and labor within a state and industry, but such variation is not driven by changes in $\bar{S}$. This would be the case, for example, if car plants in Ohio vary their labor and capital inputs by different amounts, but such changes are not correlated with changes in college share across Ohio cities in industries other than car. The assumption is not correct if changes over time in capital and labor are both correlated with changes in $\bar{S}$ within a state and industry, and correlated with unobserved productivity shocks within state and industry. This would be the case if car plants in Cleveland, experiencing a

\footnotetext{
${ }^{11}$ For example, if productivity increases in computer firms located in Silicon Valley and this increased productivity attract college educated workers to Silicon Valley, this would not constitute a source of bias. Presumably all computer producers across the nation or at least in California would be experiencing similar increase in productivity, and industry $\times$ year $\times$ state effects would absorb this unobserved shock.
} 
larger productivity increase than car plants in Cincinnati, raise their labor and capital inputs more than car plants in Cincinnati, and at the same time the number of college graduates employed in industries other than cars increase more in Cleveland than in Cincinnati.

In the next section, I provide some indirect evidence on the validity of my assumptions.

\subsection{Four Specification Tests}

Although I can not completely rule out the possibility that estimates of equation 4 reflect unobserved city wide, time-varying productivity shocks, I further investigate the validity of my identifying assumptions using four specification tests.

(1) Using Physical Capital Instead of Human Capital. First, I repeat the analysis substituting human capital outside the plant with a measure of overall physical capital outside the plant. If my estimate of human capital spillovers are spurious, or if they can be explained by agglomeration effects other than human capital externalities, then I may find that plants located in cities where the overall level of physical capital is high are more productive than similar plants located in cities where the overall level of physical capital is low. On the contrary, if my estimates are capturing only human capital externalities, there is no reason why physical capital in one plant should be correlated with productivity in other plants.

Empirically, I find that the overall stock of physical capital in a city outside a plant has no effect on a plant's productivity.

(2) Spillovers Within a City Should Decline with Economic Distance. As a second specification check, I test whether the magnitude of spillovers between industries depends on their level of interaction. Specifically, I investigate whether human capital spillovers within a city between industries that are economically close (and therefore often interact) are larger than spillovers between industries that are economically distant (and therefore rarely interact). Within a city, workers are likely to interact more with other workers in industries that are economically close. I expect spillovers to be large between industries that interact often and zero between industries that never interact. Finding that human capital spillovers are large between industries that are located in the same city but seldom interact would be surprising 
and may indicate that my estimates are polluted by city-wide productivity shocks. ${ }^{12}$

The key question is how to measure interaction between industries. Because the exact mechanism of the spillover is not known, the choice of a metric is necessarily arbitrary. I use input-output tables. The input-output tables seem a reasonable choice to measure how industries interact, because they provide detailed information on the flows of the goods and services that make up the production process of industries. Specifically, the input-output tables show how industries provide input to, and use output from, each other. I assume that the level of interaction between manufacturing and each of the 1-digit industries is proportional to the value of inputs that each industry provides to manufacturing. According to this assumption, the industry "transportation, communication and utilities" interacts with manufacturing more frequently than "finance" because the value of inputs from "transportation, communication and utilities" that are used in manufacturing is larger than the value of inputs from "finance".

Empirical results confirm that the magnitude of the spillovers between industries is a function of their degree of interaction. Specifically, I find that the level of human capital in industries that are located in a given city and often interact with manufacturing has a larger effect on the productivity of manufacturing plants in that city than the level of human capital in industries that are located in the same city but never interact with manufacturing.

\section{(3) Spillovers Should Be Larger for Hi Tech and Human Capital Intensive Pro-}

ductions. As a third specification check, I test whether productions that are more "knowledge intensive" benefit more from human capital spillovers than productions that are less "knowledge intensive". I expect human capital spillovers to matter more for the production of advanced, hi-tech products (computers, scientific equipment, bio-tech, or pharmaceutical) than for the production of mature, low tech products (cement, steel or lumber). If I found that human capital spillovers were more important for cement plants than computers or bio-tech plants, then that would cast doubt on the interpretation of the spillovers.

First, I stratify the sample by hi-tech status. I find that most of the estimated spillover come from hi-tech plants. The spillover for non hi-tech plants is virtually zero. Second, I

\footnotetext{
${ }^{12}$ I focus on economic distance instead of geographic distance because, by looking at spillovers within a city, I am already taking into account the geographical dimension of the spillover. Although it is in theory possible to look at the geographical proximity of plants within a city, information on the exact location of workers within a city is not available in the public version of the Census of Population.
} 
stratify the sample by the percentage of college educated workers in a plant. I find that the estimated spillover is larger for plants that employ a larger fraction of college graduates than for plants that employ a smaller fraction of college graduates. I interpret this result as evidence that human capital spillovers benefit more human capital intensive productions.

\section{(4) Spillovers Should be Larger for Single-Unit Plants than Multi-Unit Plants.}

As a final check, I test whether the magnitude of the estimated spillover varies by multi-unit status. Multi-unit status indicates whether a plant belongs to a firm with more than one establishment. Henderson (2001) argues that single-unit plants should be more sensitive to the level of human capital in the local environment than plants that belong to large firms with establishments in several locations. According to this view, plants that belong to multiestablishment firms are more insulated from local environments and depend more on internalfirm networks. For example, while many of the factors that affect the productivity of a General Motors' plant located in St. Louis are probably determined in the General Motors' headquarters in Detroit, all the factors that affect the productivity of a single-unit plant in St. Louis are determined in St. Louis.

Empirically, I find that the estimated spillover is significantly larger in single unit plants than in multi-unit plants.

\section{Data}

The data come from a unique match between plant records from the Census of Manufacturing in 1982 and 1992 and worker records from the Census of Population. The Census of Manufacturers is a longitudinal dataset that covers the universe of manufacturing establishments with one paid employee or more. The unit of observation in the Census of Manufacturers is the plant. ${ }^{13}$ Two important advantages of the Census of Manufacturers are its panel structure, and a sample size large enough to allow a disaggregation of the data by metropolitan area.

Although the Census of Manufacturers contains detailed information on the number of hours worked in each plant, information on the education level of workers is not reported. To obtain data on workers' education, I match workers in the 1980 and 1990 Censuses of

\footnotetext{
${ }^{13} \mathrm{~A}$ company operating at more than one location is required to file a separate report for each location.
} 
Population to firms in the Census of Manufacturers, by industry and city. Specifically, I assign each plant in the Census of Manufacturers and each worker in the Census of Population to a city-industry cell based on the metropolitan area code and a 3-digit industry definition. The 3-digit industry definition is quite detailed, so that the cells are narrow. Examples of 3-digit industries include: iron and steel foundries (SIC 332); engines and turbines (SIC 351); electronic computing equipment (SIC 357); soaps and cosmetics (SIC 284). For each city-industry cell, I use the Census of Population to calculate the fraction of hours worked by individuals with college, some college, high school and less than high school. I combine this information with plant level information on the total number of hours worked from the Census of manufacturers to impute the number of hours worked by each education group in each plant.

For city-industry cells for which there is only one plant, the matching is exact. In some cells, however, there is more than one plant. One example is "Motor Vehicles and Passenger Car Bodies" (SIC 371) in Detroit. For cells for which there are more than one plant, the imputation is based on the assumption that the fraction of hours worked by each education group is the same for all plants in the same cell. In the Detroit example, this assumption allows "Motor Vehicles and Passenger Car Bodies" plants in Detroit to have different number of hours worked, but requires the fraction of hours worked by college graduates, individuals with some college, high school graduates and high school drop out to be the same for all plants in that industry. The Data Appendix provides a detailed description of the Census of Population and Census of Manufacturers and the matching algorithm. The matched sample is a balanced panel with 40,281 plants. Descriptive statistics for the matched sample are reported in Table 1.

Since plants in cities with more educated labor force are more likely to employ educated workers, obtaining a good estimate of the skill distribution in each plant is particularly important. Failing to adequately control for the skill level of workers in the plant may result in an upward bias in the estimated spillover. To assess the quality of the match of workers and plants, I do two things. First, I re-estimate all the models in the paper using an alternative strategy to control for the skill level in a plant. Although the Census of Manufacturers does not report the education distribution in a plant, it does report the number of hours worked by production and non production workers in each plant-basically hours worked by blue and white collar workers. The advantage of using information on production and non production workers is that no imputation is required. By using exclusively Census of Manufacturers data, 
this strategy reduces the amount of measurement error that arises from the imputation. On the other hand, this specification has the disadvantage that the distinction between production and non production workers may account only imperfectly for workers' skill level. ${ }^{14}$ Empirically, I show below that controlling for workers' imputed education and controlling for workers' production/non production status, makes little difference: empirical estimates obtained under the two alternative approaches are similar.

As a second way to check the reliability of the matched worker-firm data, I estimate plantlevel wage equations. If the matching is correct and measurement error is not too large, I expect wage equation coefficients to be close to the ones usually found in the wage equation literature. I show in the Appendix that this in fact seems to be the case.

In interpreting the results I present below, it is important to bear in mind a limitation of the data. The longitudinal dataset that I use is not necessarily representative of the full population of plants, because it only includes plants that are observed both in 1982 and 1992. One consequence is that large plants are more likely to be in the sample. (Note, however, that by controlling for capital and labor inputs, I am effectively controlling for plant size.) In some models, I re-weight the observations so that the distribution of plant size and other observables plant characteristics reproduces the distribution in the original population (see Section 5.6). ${ }^{15}$

The key independent variable is college share in the city outside the industry, $\bar{S}_{-j c t}$. I use the Census of Population to obtain an estimate of $\bar{S}_{-j c t}$. An alternative specification would be to use average years of schooling instead of college share. There is not obvious a priori reason to choose one measure of aggregate human capital over the other. ${ }^{16}$ I re-estimated all the models using average schooling instead of college share, and obtained results that are qualitatively similar to the one presented here.

\footnotetext{
${ }^{14}$ Although the number of hours worked by non production workers is correlated with the number of hours worked by college graduates, the correlation is not perfect (Doms, Dunne and Troske 1997).

${ }^{15} \mathrm{I}$ have also looked at whether the probability that a plant exists in 1982 but not in 1992 is correlated with the change in the city college share. I find that this is not the case.

${ }^{16}$ In previous work I have used college share (Moretti forthcoming).
} 


\section{Empirical Results}

\subsection{Plant-Level Estimates of Production Functions}

I now turn to the empirical results. As dependent variable, I can use either value of shipments or value added, which is value of shipments minus cost of materials. Previous literature suggests that neither measure is perfect. ${ }^{17}$ Empirically it makes little difference which dependent variable is used. I present results based on value added, but I have re-estimated all the models using value of shipments and obtained identical results. I also report results based on value of shipments in Table 10 below.

I begin by presenting cross-sectional estimates of plant-level production functions. Columns 1 and 2 in Table 2 refer to a specification where technology is Cobb-Douglas. The coefficient $\gamma$ on college share outside the industry in columns 1 and 2 is 0.84 in 1992 and 0.81 in 1982 , indicating that a one percentage point increase in the overall share of college graduates in the city (excluding the industry a plant belongs to) is associated with an increase in productivity by $0.8 \%$. Through the paper, standard errors are corrected for city-year clustering.

The models control for capital stock, hours worked by skilled and unskilled labor, a dummy equal to one if the plant belongs to a multi-unit firm, and 3-digit industry dummies. Capital stock for equipment and structures is measured from the book values deflated by capital stock deflators. ${ }^{18}$ Hours worked by unskilled workers are hours worked by workers who have a highschool degree or less. Hours worked by skilled workers are hours worked by college graduates or workers with some college. Later, I show that alternative definitions of skilled and unskilled labor yield similar estimates. ${ }^{19}$ Columns 3 and 4 refer to a specification where technology is

\footnotetext{
${ }^{17}$ Hellerstein, Neumark and Troske (1999) point out that value added has two advantages over value of shipments. First, a value-added specification can be derived from polar production functions: one in which the elasticity of substitution between materials and value-added in infinite; and one in which this elasticity of substitution is zero. Second, a value of shipment specification requires to include value of materials on the right hand side. This specification may be problematic given the potential endogeneity of materials. Hellerstein et al. (1999) experiment with both the value added specification and with a production function where materials are on the right hand side, and instrumental variables are used to account for endogeneity of materials. Results are similar in the two specifications.

${ }^{18}$ The deflator is obtained as the ratio of the current dollar book value to the constant dollar value for the two-digit industry from the Bureau of Economic Analysis (Foster, Haltiwanger and Krizan 1998).

${ }^{19}$ The coefficient on log number of hours worked by unskilled workers is 0.47 in 1992, and the corresponding coefficient for skilled workers is 0.38 . The 1992 coefficient on skilled labor is larger than the 1982 one, while the 1992 coefficient on unskilled labor is smaller. This is consistent with the increased return to schooling documented in studies that focus on wages. I have experimented with alternative definitions of skilled and unskilled labor. For example, in some specifications I allow for four skill groups instead of two: less than high school, high school, some college and college. I have also estimated models where the $\alpha$ 's are allowed to very
} 
translog. The coefficient on college share is invariant to this change.

I now turn to longitudinal models. Table 3 reports estimates of variants of equation 4 . Column 1 is analogous to the models in table 2 but adds plant fixed effects. Identification of the spillover comes from changes in productivity and college share between 1982 and 1992 . The coefficient on college share in column 1 is 0.74 . Plant fixed effects purge estimates of permanent plant and city unobserved heterogeneity. The fixed effects estimator may still be biased if there are transitory unobserved factors that affect both changes in college share and changes in productivity. In the specifications in columns 2,3 and 4 , I include respectively industry $\times$ year dummies, state $\times$ year dummies and industry $\times$ state $\times$ year dummies. The coefficients are between 0.51 and 0.77 .

In the specification used in columns 1 to 4 , the intercept of the production function is allowed to vary across plants, but the slope coefficients are constrained to be the same. In reality, however, it is possible that the relative importance of capital and labor varies across industries. In column 5, I relax the restriction that technology is the same across industries and allow the slope coefficients on capital and labor to vary by 2-digit industry. The coefficient in column 5 is slightly smaller to the one in column 4.

Finally, in column 6 to 10, the assumption of Cobb-Douglas technology is relaxed and a more general Translog production function is estimated. The coefficient on college share is generally lower, but not statistically different from the one obtained from the corresponding Cobb-Douglas specification.

From Table 3, I conclude that estimates of the coefficient on college share outside the industry are generally robust to different specifications. After controlling for a plant's own level of human capital, plants located in areas where the overall level of human capital increased became more productive than similar plants located in areas where the overall level of human capital did not change. This increased productivity does not seem to be driven by industry specific or state specific shocks because it is robust to the inclusion of state $\times$ year and industry $\times$ year dummies. Without a randomized experiment, it is difficult to be certain that the estimated correlations are causal. It is always possible that the estimates reflect, at least in part, the presence of city wide, time varying productivity shocks correlated with $\bar{S}$. However, findings in Table 3 show that the estimates of the spillover are robust to a wide variety of assumptions over time or across cities. See Section 5.6. 
on technology and demand shocks. In the next section, I provide further evidence that my estimates are not completely spurious.

According to the most robust estimate in table 3 (column 10), an increase of one percentage point in college share outside the industry is associated with a productivity increase equal to $0.6 \%$. To help interpret the magnitude of the coefficient, consider that the average yearly increase in college share between 1982 and 1992 was about 0.2 percentage points. According to my estimate, an increase in college share of 0.2 percentage points would be associated with an increase in output by about $0.12 \%$. For the average plant in the U.S., this amounts to about $\$ 10,000$ per year. I discuss the magnitude of the estimated effect in Section 6 .

\subsection{Does Average Physical Capital Matter as Well?}

I now turn to the four specification checks described in section 3.3. First, I estimate equation 4 substituting human capital with a measure of overall physical capital outside a plant. If my estimates are spurious, or if they can be explained by agglomeration effects other than human capital externalities, then I may find a positive correlation between productivity and the overall density of physical capital in a city. On the contrary, if my estimates are capturing only human capital externalities, there is no reason why physical capital in one plant should be correlated with productivity in other plants.

For each plant and city, I use two alternative measures of density of physical capital: the log of average physical capital outside the plant in the city and the log of per worker average physical capital outside the plant in the city. Cross-sectional estimates in Table 4 suggest that average capital is correlated with productivity, although the sign is positive in 1982 and negative in 1992. However, when plant fixed effects are included the coefficient becomes insignificant, suggesting that plant-level heterogeneity may bias cross-sectional estimates. When state $\times$ year effects are added (column 4) or industry $\times$ year effects are added (column 5), the coefficients drop to virtually zero. I conclude that overall level of physical capital outside the plant does not have an effect on plants' productivity similar to the one generated by human capital.

\subsection{Do Human Capital Spillovers Decline with Economic Distance?}

I now test the hypothesis that spillovers within a city between industries that are economically close are larger than spillovers between industries that are economically distant. I modify 
equation 4 to include college share in manufacturing, as well as college share in Transportation; Communication and Utilities; Trade (retail and wholesale); Services; Finance, Real Estate and Insurance; Mining; and Construction:

$$
\ln y_{p j c s t}=\sum_{k} \gamma_{k} \bar{S}_{k c t}+\alpha_{1 j} \ln L 1_{p j c t} \alpha_{2 j} \ln L 2_{p j c t}+\beta_{j} \ln K_{p j c t}+d_{p}+d_{j t}+d_{s t}+\epsilon_{c t}+\epsilon_{p j c t}
$$

where $\bar{S}_{k c t}$ is now college share in industry $k$, city $c$ and year $t$; and $k$ indexes all 1-digit industries (When $k=$ Manufacturing, I calculate college share excluding 3-digit industry $j$ ). Equation 5 yields estimates of seven $\hat{\gamma}$ 's - one for each 1-digit industry.

Having obtained estimates of the $\gamma$ 's, I then test whether the magnitude of each industry's $\gamma$ coefficient depends on the economic distance between that industry and manufacturing. As anticipated in Section 3.3, I use input-output tables to measure economic distance. ${ }^{20}$ I rank non-manufacturing industries by distance from manufacturing based on the value of the inputs that each industry provides to manufacturing. According to my definition, because manufacturing uses more inputs from "transportation, communication and utilities" than from "construction", manufacturing is closer to (and interacts more with) "transportation, communication and utilities" than "construction".

Table 5 shows estimates of the $\gamma$ coefficients in equation 5 . The coefficient is largest for Manufacturing and smallest for Finance, Real Estate and Insurance. Column 2 shows economic distance, as measured by the amount of inputs in manufacturing from each industry. Although the relationship between the coefficient in column 1 and economic distance in column 2 is by no means monotonic, the estimated coefficients do tend to decrease as we move toward industries that provide fewer inputs into manufacturing. This can be better seen in Figure 2, which plots the coefficients against the rank based on value of inputs. The OLS fitted line is superimposed. The OLS slope (standard error) is -.109 (.042), and $R^{2}$ is 0.54. A similar figure is obtained if one plots the coefficients against the log value of inputs.

Figure 2 indicates that human capital in industries that are economically close to manufacturing (and presumably interact more with manufacturing) benefit manufacturing plants more than human capital in industries that are economically far from manufacturing (and presum-

\footnotetext{
${ }^{20}$ The I-O tables are based on national data. I use the "Use" Table, which shows the inputs to industry production and the commodities that are consumed by final users. The Use table is the most frequently requested table because of its applications to the estimates of GDP. Source:

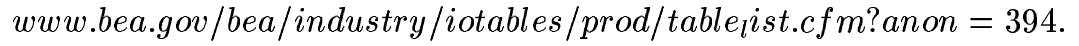


ably interact less with manufacturing). This finding is based on 1-digit industries, which are very broad. To assess how robust this result is, I repeat the analysis using a more disaggregated industry definition. Instead of looking at 1-digit industries, I look at 2 digit industries. Everything else remains the same. As before, I rank industries based on value of inputs. Table 6 shows estimates of a model where the coefficient on college share varies depending on the distance between 2-digit industries. Because there are so many 2-digit industries, I group them in sets of five. In other words, I force the coefficient on college share to be the same for the closest 5 industries, the next five and so on. Note that the industry composition in each 5industry group is different for each plant. ${ }^{21}$ For example, the entry in row 1 is the coefficient on college share in the 5 2-digit industries that are closest to the relevant plant. Like for Table 5, estimates in Table 6 show a tendency to decrease as we move from close industries to industries further away. This is more easily seen in Figure 3, that plots the estimated coefficients against the rank based on value of inputs. The OLS fitted line is superimposed. The slope (standard error) of the line is $-0.015(0.002)$.

Overall, from Figures 2 and 3, I conclude that, within a city, spillovers decay with economic distance, when distance is measured by value of inputs. If value of inputs is a valid proxy for how much industries interact with each other, results in this section support the view that spillover are related to the amount of interactions between workers in different industries.

\subsection{Are Human Capital Spillovers More Important for "Knowledge- Intensive" Productions?}

I now turn to the hypothesis that human capital spillovers are more important for productions that are "knowledge intensive". I use two alternative definitions of "knowledge intensity". First, I classify productions as hi-tech or low tech. As argued in Section 3.3, I expect the effect of human capital spillovers to be larger for hi-tech productions. I use the definition of high-tech industries provided by the American Electronic Association (1997) based on 45 4-digit SIC codes. $^{22}$ According to this definition, about $9 \%$ of the plants in the sample are hi-tech.

\footnotetext{
${ }^{21}$ For example, the 5 industries that are closest to plants in industry $j$ are different from the 5 industries that are closest to plants in industry $k$.

${ }^{22}$ The definition includes computers and office equipment, consumer electronics, communication equipment, electronic components, semiconductors, industrial electronics, photonics, defense electronics, electromedical equipment, software and computer related services, telecommunication services.
} 
The estimates in column 1 of Table 7 suggest that most of the effect of college share on productivity comes from hi-tech plants. The coefficient on college share for non hi-tech plants is 0.228 , and not significantly different from 0 . The coefficient on the interaction on college share and a high-tech dummy is almost ten times larger, 2.189, and significantly different from 0 . Including industry $\times$ year effects has little impact, while including state $\times$ year effects significantly reduces the coefficient on the interaction term. In column 4 , where industry $\times$ state $\times$ year are included, the coefficient on the interaction is 1.68 , while the coefficient for all other plants is 0.57. According to this last specification, the effect of college share on the productivity of high tech plants is $2.25(0.057+1.68)$, which is three times larger than the corresponding average effect in Table 3, column 5 .

In the last column of table 7 , I include city $\times$ year effects. This model is the most robust one, because all city wide, time-varying factors that may introduce spurious correlation between productivity and college share are controlled for. Because I include a dummy for each city and year pair, I cannot identify the level of the spillover, but only the difference in the spillover between hi and low tech plants. ${ }^{23}$ The coefficient on the interaction college share $\times$ hi tech is 1.1. This suggests that the coefficient in column 4 is upward biased because of city-time specific heterogeneity. However, even after controlling for city $\times$ year effects, human capital spillovers remain significantly larger for high tech firms than for all other firms.

As an alternative definition of "knowledge intensity", I use plant level measures of the importance of human capital in production. I use two alternative measures: the percentage of college educated workers in the plant and the percentage of non-production workers in the plant. In plants where a large share of workers is college educated, human capital is presumably a more important factor of production than in plants where a large share workers is without a college education. As argued in Section 3.3, I expect that human capital spillovers are more important in such plants. Similarly, the share of non-production workers is also a reasonable indicator of how important human capital is for a particular production (Berman, Bound and Griliches 1994). ${ }^{24}$

\footnotetext{
${ }^{23}$ I can not identify the level of the spillover because $\bar{S}_{-j c t}$ varies almost exclusively at the city-year level, and it is almost completely absorbed by the city $\times$ year dummies. Variation of $\bar{S}_{-j c t}$ within a city and year is minimal.

${ }^{24}$ I have also experimented with variations of these two alternative measures. For example, I have used the share of non-production wages, instead of the share of non-production workers. I have also tried the percentage of workers with some college or college, instead of the share of college graduates only. Results are qualitatively similar.
} 
I divide the plants in three groups: plants where non-production workers are less than a third of the labor force, between a third and two thirds, and more than two thirds. The top panel of Table 8 shows estimates of a regression where I interact college share outside the industry with indicators for the three groups. For plants where non-production workers are less than a third, the coefficient is 0.478 . The coefficient is twice as large for plants where the non-production workers are between a third and two third of the total labor force, and three times larger for plants where non production workers are more than two third of the total labor force.

In the bottom panel of Table 8, I use the fraction of college educated workers in the plant, instead of the fraction of non-production workers. Results are similar to the results in the top panel. The coefficients increases from 0.40 for plants with less than a third college graduates, to 0.47 for plants where college graduates are between a third and two thirds of the total, to 2.6 for plants where college graduates are more than two third of the total. Overall, findings in Table 7 and 8 are consistent with the notion that human capital spillovers have a larger effect on productions that are "knowledge intensive".

\subsection{Is the Spillover Larger in Single Unit Plants?}

As a final specification check, I investigate whether the estimated spillover varies by multi-unit status. As argued above, single unit plants are expected to be more sensitive to the local environment, while large multi-unit plants should be less affected. Table 9 shows that the coefficient on college share is 0.91 for single-unit plants and only 0.42 for multi-unit plants. This confirms that changes in the overall level of education of the work force in a city have a larger impact on the productivity of single-unit plants than they do on multi-establishment corporations.

Although alternative explanations are always possible, taken together, the findings from the four specification tests described in Sections 5.2 to 5.5 lend support to the view that the estimate of the spillovers are not completely spurious.

\subsection{Robustness Checks}

I conclude this section by presenting estimates from a number of alternative specifications intended to probe the robustness of the results in Table 3. The first row in table 10 reproduces 
the estimate for the base specification in Table 3, column 1. The remaining rows present estimates of variants of the base model. The second row reports the estimate from a specification similar to the base specification, where the dependent variable is value of shipments, not value added. The coefficient increases to 0.86 .

In section 4 , I pointed out that results in this paper are based on a selected sample of plants that are observed both in 1982 and 1992. Plants in the selected sample are larger than plants in the population. In row 3, I re-weight the sample to make the plant size distribution look like the distribution in the 1982 population. I assign weights based on plant size: smaller plants receive more weights than larger plants. ${ }^{25}$ After the re-weighting, observable characteristics of plants are similar to the ones in the population in 1982. The coefficient from the weighted regression in row 3 is $0.694 .^{26}$ In the next three rows, I investigate whether the estimated coefficient varies with plant size. No obvious pattern emerges. For small plants (less than 10 workers), the coefficient is 0.69 . It increases to 0.81 for medium sized plants (between 11 and 50 workers), and decreases to 0.75 for large plants (above 50 workers).

In models in rows 7, 8 and 9, I use alternative controls for the skill level of workers in the plant. In particular, in row 7 I allow for three skills levels instead of two: high school or less, some college and college. In row 8, I allow for four skills levels: less than high school, high school, some college and college. In row 9, I use plant-level information on the number of hours worked by production and non production workers from the Census of Manufacturers. As argued above, the model in row 9 has the advantage that it reduces the amount of measurement error that arises from the imputation of schooling. The coefficients in rows 7,8 and 9 are 0.68 0.52 and 0.48 , respectively.

Next, I try to address the concern that changes in workers' unobserved ability are correlated with changes in college share. It is in theory possible that workers of higher ability move to cities that experience larger increases in college share. If this is the case, the estimated spillover would reflect higher ability of educated workers in the plant, not higher productivity. Under some

\footnotetext{
${ }^{25}$ I divide the sample in 10 groups, based on the number of workers: less than 10, between 10 and 20, 20-30, etc. I assign a weight to each plant in the longitudinal sample based on the frequency of that plant's group in the 1982 Census of Manufacturers population.

${ }^{26}$ To further investigate the issue of sample selection, I have also tested whether the probability that a plant exists in 1982 but not in 1992 is correlated with changes in the level of human capital in a city, and I found little correlation. Specifically, I divide the cities in the sample in 4 quartiles, according to the change in college share between 1982 and 1992. The average probability that a plant exists in 1982 and not in 1992 for first quartile, which is the group of cities with the smallest increase in college share is 0.511 . The corresponding figures for the second, third and fourth quartile are, respectively, $0.515,0.512$ and 0.544 .
} 
assumptions, it is possible to account for workers heterogeneity by estimating models where the coefficients on skilled and unskilled labor are allowed to vary across cities and time. To see this, assume that the production function is $y_{p j c t}=A_{p j c t} L 1_{p j c t}^{* \alpha_{1}} L 2_{p j c t}^{* \alpha_{2}} K_{p j c t}^{\beta}$, where $L 1_{p j c t}^{*}$ and $L 2_{p j c t}^{*}$ are the true but unobserved skilled and unskilled labor inputs, respectively. Unlike equation 4, here $\alpha_{1}, \alpha_{2}$ and $\beta$ are assumed to be constant across industries. Assume that the true labor inputs are equal to hours worked inflated by an ability coefficient that can vary across cities and over time: $L 1_{p j c t}^{*}=L 1_{p j c t}^{\theta_{1 c t}}$, where $\mathrm{L} 1$ is hours worked (which are observed), and $\theta_{1 c t}$ is average ability of skilled workers in city c at time t (unobserved). A larger $\theta_{1 c t}$ implies higher ability. Similarly, $L 2_{p j c t}^{*}=L 2_{p j c t}^{\theta_{2 c t}}$, where $\theta_{2 c t}$ is average ability of unskilled workers. When estimating a production function that includes L1 and L2 (not $L 1^{*}$ and $L 2^{*}$ ), the concern is that changes in unobserved ability, $\theta_{1 c t}$ or $\theta_{2 c t}$, are correlated with changes in $\bar{S}_{-j c t}$. The production function becomes $\ln y_{p j c s t}=\gamma \bar{S}_{-j c t}+\left(\alpha_{1} \theta_{1 c t}\right) \ln L 1_{p j c t}+\left(\alpha_{2} \theta_{2 c t}\right) \ln L 2_{p j c t}+\beta \ln K_{p j c t}+d_{p}+d_{j t}+d_{s t}+\epsilon_{c t}+\epsilon_{p j c t}$. Under these assumptions, one way to account for workers heterogeneity, is to estimate models where the coefficients on skilled and unskilled labor vary by city and over time:

$$
\ln y_{p j c s t}=\gamma \bar{S}_{-j c t}+\alpha_{1 c t} \ln L 1_{p j c t}+\alpha_{2 c t} \ln L 2_{p j c t}+\beta \ln K_{p j c t}+d_{p}+d_{j t}+d_{s t}+\epsilon_{c t}+\epsilon_{p j c t}
$$

For example, in cities where skilled workers are of higher quality, $\alpha_{2 c t}$ is higher. Row 10 reports an estimate of equation 6 . The coefficient is 0.50 , lower than the estimate of the more restrictive model where the coefficients on skilled and unskilled labor do not vary across cities, but still positive. This lends some credibility to the view that unobserved ability is not a major source of bias. ${ }^{27}$

Finally, larger cities may make firms more productive because they allow for more subcontracting. If return to specialization are important, it is in theory possible that plants in larger cities are more productive. When I control for city population in row 11, the coefficient of interest does not change significantly. Including city size, as well as other city characteristics, including unemployment rate, percent black, percent immigrant and percent female also has little effect (row 12).

\footnotetext{
${ }^{27}$ This finding is consistent with previous work that uses longitudinal workers level data and finds that quality of workers does not seems to be systematically correlated with college share (Moretti forthcoming).
} 


\section{Is The Magnitude of Human Capital Spillovers Plau- sible?}

The most robust estimates of the spillover indicate that, on average, a one percentage point increase in city college share is associated with a 0.5-0.7 percent increase in productivity (Tables 3 and 10). Is this a plausible magnitude? One way to assess the plausibility of the estimated effect is to compare it with the difference in labor costs between cities with high and low human capital. In equilibrium, if firms are really more productive in cities with high levels of human capital, production costs should also be higher. Otherwise, firms would relocate from cities with low human capital to cities with high human capital (see Section 2). The difference in labor costs between cities with high and low human capital is therefore a useful benchmark against which to compare the estimated effect of human capital spillovers on productivity. Finding that the productivity differences between cities with high human capital and low human capital are larger than the differences in labor costs (adjusted for the fraction of labor cost to total costs), would suggest that the estimated productivity gains from spillovers are too large, and would cast doubt on the findings in Section $5 .^{28}$

Manufacturing wages are indeed higher in cities where the number of college graduates is high, even after controlling for individual schooling. Compare a city with a large stock of skilled workers like Seattle, WA, with a city with a much smaller stock of skilled workers, like El Paso, TX. The share of college graduates in Seattle labor force is 0.31 , almost double the share of college graduates in El Paso, 0.16. After controlling for individual schooling, and other workers characteristics, average manufacturing wages in Seattle are $20 \%$ higher than in El Paso. This implies that an extra percentage point in college share is associated with 1.3 percentage point higher wages, after controlling for individual observables. As it turns out, the corresponding figure for all US cities is 1.2 , not very different. ${ }^{29}$

\footnotetext{
${ }^{28} \mathrm{I}$ am abstracting from the cost of capital and land because: (1) the cost of capital does not vary much across cities; and (2) land is not an important input for manufacturing. If a substantial part of production costs of manufacturing firms come from land prices, and if cities with higher college share have more expensive land, then it would be possible to find that productivity differences between cities with high human capital and low human capital are larger than the differences in labor costs.

${ }^{29}$ This figure comes from an individual level OLS regression of log wage on city college share, a vector of individual characteristics including education, sex, race, Hispanic origin, U.S. citizenship and a quadratic term in potential experience, and city and year fixed effects. The coefficient (standard error) on college share is 1.2 (0.11). The sample includes all manufacturing workers in the 1980 and 1990 Census. There are 282 cities. Instrumental variable estimates and panel data estimates of the same model yield similar coefficients. See
} 
Assume for a moment that the above correlation is an unbiased estimate of the effect of college share on wages. In equilibrium, this wage difference must reflect productivity differences. Because manufacturing firms produce goods that are traded on the national market, if workers weren't more productive in high-wage cities, manufacturing firms would leave and relocate to low wage cities. Specifically, we should observe that the productivity increase associated with a one percentage point increase in college share is roughly $1.2^{*} 0.7 \simeq 0.8$, where 0.7 is the share of output that is typically assumed to go to labor (the remaining 0.3 goes to capital). In other words, if the documented correlation between college share and wages is not spurious, this back of the envelope calculation suggests that a regression of log output on college share (holding constant other inputs) should yield a coefficient not very far from 0.8 . On the other hand, if part of the documented difference in labor costs between cities with high a low human capital is due to unobserved heterogeneity, the effect of college share on output should be less than 0.8. In any case, the effect of college share on output should not be larger than 0.8 .

The estimated effect of college share on output is less than 0.8. My most robust estimates in Table 3 place the spillover effect at around 0.5-0.7. I conclude that the estimated productivity differences between cities with high and low levels of human capital are consistent with differences in labor costs that are typically observed between cities with high and low level of human capital.

\section{Conclusion}

Economists have long speculated that human capital may generate significant spillovers. Lucas (1988), among others, argues that human capital externalities are large enough to explain differences between poor and rich countries in long run growth rates. Yet, despite significant policy implications, systematic empirical evidence on the actual magnitude of externalities is just beginning to emerge. Previous work has focused on differences in education and wages across metropolitan areas.

In this paper, I take a more direct approach by focusing on the productivity of manufacturing establishments. I start from a very simple observation: if human capital spillovers actually exist, then we should observe that plants in cities with a large stock of human capital are more

Moretti (forthcoming) for details. 
productive than otherwise similar plants in cities with a smaller stock of human capital. My findings suggest that, after controlling for a plant own level of human capital, plants located in cities where the fraction of college graduates grew faster experienced larger increases in productivity than similar plants in cities where the fraction of college graduates grew more slowly. Although I control for permanent plant characteristics and state and industry timevarying productivity shocks, I can not completely rule out the possibility that unobserved city heterogeneity may explain part of the estimated effect. However, several considerations suggest that the estimated effect is not completely spurious.

First, the estimated coefficient is remarkably robust across specifications. Different assumption on technology, omitted variables, and variable definitions all yields similar results.

Second, the estimated productivity differences between cities with high and low levels of human capital are consistent with differences in manufacturing wages that are typically observed between cities with high and low level of human capital. Consistent with a model that includes both standard general equilibrium forces and spillovers, the productivity gains generated by human capital spillover appear to be offset by increased labor costs.

Third, unlike density of human capital, density of physical capital outside a plant has no effect on the plant productivity. This indicates that what I am estimating is not simply an agglomeration effect generated by density of economic activity.

Fourth, spillovers decay with economic distance within a city. Manufacturing plants benefit more from human capital in industries that are geographically and economically close to manufacturing than from human capital in industries that are geographically close but economically far. This result supports the view that spillovers are related to the amount of interactions between workers in different industries.

Fifth, the estimated spillover is large for hi-tech plants and plants that employ mostly skilled labor. It is zero for low tech plants and plants that employ mostly unskilled labor. This indicates that human capital externalities are more important for productions that are knowledge intensive. Finally, the estimated spillover is large for single unit plants, and small for multi establishments corporations that have plants in many different cities.

I conclude that productivity gains from human capital spillovers appear to be empirically relevant for U.S. manufacturing. However, because the stock of human capital grows slowly over time, the contribution of human capital spillovers to economic growth is not large. The 
most robust estimates in this paper indicate that human capital spillovers are responsible for an average of $0.1 \%$ increase in output per year during the 1980 s. For the average manufacturing plant in the U.S., this amounts to about $\$ 10,000$ per year.

Having established the existence of human capital spillovers, one important direction for future research should be the investigation of the exact mechanisms through which spillovers arise. 


\section{References}

Acemoglu, D. (1996), 'A microfundation for social increasing returns in human capital accumulation', Quarterly Journal of Economics pp. 779-804.

Acemoglu, D. and Angrist, J. (1999), 'How large are human capital externalities? evidence from compulsory schooling laws', $M I T$.

American Electronics Association (1997), 'Aea definition of the high-tech sector', Cyberstates .

Berman, E., Bound, J. and Griliches, Z. (1994), 'Changes in the demand for skilled labor within u.s. manufacturing: Evidence from the annual survey of manufactures', Quarterly Journal of Economics 109, 367-397.

Ciccone and Peri (2002), 'Identifying human capital externalities: Theory with application to us cities', mimeo .

Doms, M., Dunne, T. and Troske, K. R. (1997), 'Workers, wages, and technology', Quarterly Journal of Economics 112, 253-290.

Foster, L., Haltiwanger, J. and Krizan, C. (1998), 'Aggregate productivity growth: Lessons from microeconomic evidence', NBER Working Paper (6803).

Glaeser, E. L. (1999), 'Learning in cities', Journal of Urban Economics 46(2), 254-77.

Glaeser, E. L. and Mare, D. C. (2001), 'Cities and skills', JOLE 19.

Glaeser, E. L., Scheinkman, J. A. and Shleifer, A. (1995), 'Economic growth in a cross-section of cities', Journal of Monetary Economics 36(1).

Hellerstein, J. K., Neumark, D. and Troske, K. R. (1999), 'Wages, productivity and worker characteristics: Evidence from plant-level production functions and wage equations', Quarterly Journal of Economics 17(3), 409-447.

Henderson, V. (2001), 'Marshall's scale economies', Brown University mimeo .

Jaffe, A., Trajtenberg, M. and Henderson, R. (1993), 'Geographic localization of knowledge spillovers as evidenced by patent citation', Quaterly Journal of Economics 108(3), 577598.

Jovanovic, B. and Rob, R. (1989), 'The growth and diffusion of knowledge', Review of Economic Studies 56(4), 569-582.

Kominsky and Siegel (1994), 'Measuring educational attainment in the cps', Population Division, US Bureau of Census .

Lucas, R. E. (1988), 'On the mechanics of economic development', Journal of Monetary Economics 22, 3-42.

Marshall, A. (1890), Principles of Economics, Macmillan.

Moretti, E. (forthcoming), 'Estimating the external return to higher education: Evidence from cross-sectional and longitudinal data', Journal of Econometrics .

Rauch, J. E. (1993), 'Productivity gains from geographic concentration of human capital: Evidence from the cities', Journal of Urban Economics 34, 380-400.

Roback, J. (1982), 'Wages, rents and the quality of life', Journal of Political Economy 90(6), 1257-1278. 
Roback, J. (1988), 'Wages, rents and amenities: Differences among workers and regions', Economic Inquiry 26(1), 23-41.

Zucker, L. G., Darby, M. R. and Brewer, M. B. (1998), 'Intellectual human capital and the birth of u.s. biotechnology enterprises', American Economic Review 88(1), 290-306. 


\section{DATA APPENDIX}

CENSUS OF MANUFACTURERS: Plant level data on output, capital, hours worked, industry and metropolitan area are from the Census of manufacturers. The Census of Manufacturers covers the universe of manufacturing plants with 1 or more employees. Since Standard Metropolitan Statistical Area (SMSA) codes in different years are based on different definitions of metropolitan areas, I correct the 1992 SMSA code to be consistent with the 1982 definition. I delete all the SMSA that are new to the '92 sample and were not part of another SMSA in '82. ${ }^{30}$ Because the metropolitan area definition was changed after 1982, I also redefine 1992 SMSAs to match the 1982 boundaries. I do this in two steps. First, I make the definition of counties consistent over time because some counties have changed their boundaries during the 1980s and there are coding errors in the Census of Manufacturers county code. To do so, I use a program written by Randy Becker and provided by CES. Only 5 urban counties are affected (they are located in Georgia, Virginia, Arizona, New Mexico and California). To make sure that all county changes have been captured, I use the County Group Equivalency. I find 7 more changes in Virginia counties that are not included in the CES program. Once I have a county code that is consistent over time, I use the County Group Equivalency files to identify SMSA boundary changes in the 1992 Census of Manufacturers. 263 SMSAs are identified in 1982 and 1992.

I assign each plant to an industry-city cell based on 3-digit SIC code and SMSA code. Although 4-digit SIC codes are available, I choose 3-digit industries to maximize consistency with the Census of Population industry classification. For production workers, both the number of workers and the number of hours worked is reported in the Census of Manufacturers. For non-production workers, the number of workers is known, but the number of hours worked is not reported. The number of hours of non-production workers is imputed by assuming that production and non-production workers in the same plant work the same number of hours per capita.

CENSUS OF POPULATION: Data on the skill level of workers in each plant and on the share of college graduates outside the industry come from the 1980 and 1990 Censuses of Population. To maximize sample size, I use the $5 \%$ version of the Public Use Microdata Sample (PUMS). The Census industry classification is not the SIC one, but has a similar level of detail as the 3-digit SIC codes. Using the name of the industry, I match the Census industry classification to the SIC one.

As in the Census of Manufacturers, metropolitan area definitions are not consistent across years. To make the 1990 SMSA codes consistent with the 1980 definition, I adopt a procedure consistent with the one described above for the Census of Manufacturers. ${ }^{31}$ Years of education

\footnotetext{
${ }^{30} \mathrm{I}$ also delete Dayton because it was combined with Springfield, $\mathrm{OH}$ and there isn't a good way to separate them and/or to define either one so that it resembles its form in 1982.

${ }^{31}$ Specifically, I assign individuals a metropolitan area on the basis of two geographical identifiers, Public Use Microdata Areas (PUMAs) and metropolitan area codes. The finest geographic units identified in the $5 \%$ samples are PUMAs, which are arbitrary geographic divisions that contain no less than 100,000 people each. Most individuals who live in metropolitan areas are also assigned a metropolitan area identifier. However, some PUMAs straddle the boundary of two or more SMSAs and in these 'mixed' PUMAs an SMSA code is not assigned. These 'mixed' PUMAs are assigned a SMSA code on the basis of the County Group Equivalency files. The methodology used to assign SMSA codes and to match MSA across Censuses is identical to the one in Moretti (forthcoming). If over 50\% of the PUMA population is attributable to a single MSA, I then assign all individuals in that PUMA to the majority MSA. Since the MSA definition was changed after the 1980 Census,
} 
are assigned to the education codes used in 1990 Census following Table 1 in Kominsky and Siegel (1996). Since 1982 and 1992 are not Census of Population years, linear interpolation is used to estimate the college share for 1982 and $1992 .{ }^{32}$

MATCHING CENSUS OF MANUFACTURERS TO CENSUS OF POPULATION: Plant-level data from the Census of Manufacturers are matched with data on workers education by industry and city. I assign each plant in the Census of Manufacturers and each worker in the Census of Population to a city-industry cell based on the metropolitan area code and a 3-digit industry definition. To minimize the amount of measurement error, I exclude all industry-city cells with less than 10 workers. There are a total of 3441 cells. The average number of workers in a cell is 546 in 1980 and 387 in 1990. About $18 \%$ of cells contain only one plant. (The fraction of cells that include only one plant is calculated for the balanced panel used for regressions, not for the population of plants.) The median cell in 1992 includes 100 workers and 4 plants. ${ }^{33}$

The Census of Manufacturers has 381,773 plants in 1982 and 348,385 in 1992. To build the balanced panel used in this paper, I first exclude all plants that do not appear both in 1982 and 1992. 161,321 plants exist in both years. I then delete plants for which some of the relevant variables are missing in at least one year. I also exclude from the sample all plants that have capital or production hours or non production hours equal zero. With Cobb-Douglas or Translog production functions, output is zero for any plants where one of the inputs is zero. Finally, after I delete industry-city cells with less than 10 workers from the Census of Population. The resulting balanced panel sample has 40,281 plants in 1982 and 1992. This sample covers approximately $24 \%$ of average annual manufacturing employment over the period from 1982 to 1992. Large plants are overrepresented in the worker-firm matched sample. For example, the average number of hours worked by all plants in 1982 is 105.2, less than half than the average number of hours worked by plants in the matched sample. Similarly, output, value added, value of capital and wages are lower in the population than in my sample. The average output, added value, capital and wages in the population of plants in 1982 are, respectively: 9018; 3828; 3336; 12.2. However, the non representativeness of the worker-firm matched sample does not seem to bias the estimates in any significant way (see Section 5.6).

In theory, the Worker Establishment Characteristics Database (WECD) could have been used instead of the sample used here. WECD matches Census of Manufacturers to Census of Population using a more precise algorithm that requires eliminating from the sample all observations located in cells with more than one plant (Hellerstein et al. 1999). The main

I redefine 1990 SMSAs to match the 1980 boundaries. The County Group Equivalency files are used to identify PUMAs that contain the affected counties in the 1990 Census. If the counties in question comprise more than half of the PUMAs population, all respondents are assigned to the pertinent SMSA. If more than $10 \%$ of a SMSAs 1990 population is affected by the boundary changes and is unrecoverable from the County Equivalency files, I drop the city from the analysis. Dayton and Springfield, Ohio are the only such cities. 282 SMSAs are identified in 1980 and 1990. The computer code for this assignment is available on request.

${ }^{32} \mathrm{An}$ alternative would have been to use averages obtained yearly from the Current Population Survey. Given the smaller sample size of the CPS, results obtained by interpolating Census averages turn out to be more precise than results obtained from CPS averages.

${ }^{33}$ There is a wide variation in cell size across industries. For example, Petroleum Refining (SIC 291) and Engine and Turbines (SIC 351) have typically only one plant per cell, while Plastic Products (SIC 308) and Scientific Instruments (SIC 381, 382) have 7 plants per cell. Not all industries are present in all cities. For example, Office and Accounting Machines (SIC 357) plants are present in only 29 cities, while there are Electrical Machinery (SIC 361, 362, 364, 367, 369) plants in 197 different cities. 
reason why I do not use WECD is that it is available only for 1992 and does not allow for a longitudinal analysis.

Plant-Level Wage Equations: In order to asses the quality of the match of workers and plants, I have estimated plant-level wage equations. Although the focus of this paper is not on wages, plant-level wage equations provide an indirect test of the quality of the matching. If the matching is correct and measurement error is not too large, one would expect wage equation coefficients to be close to the ones usually found in the wage equation literature. ${ }^{34}$ The estimated wage equations are shown in table A1. Data on wages, from the Census of Manufacturers, are plant averages obtained by dividing the total wage bill by the number of hours worked. Data on workers are cell averages from the Census of Population. For example, "percentage female" is the fraction of women in the industry and city to which the plant belongs. The coefficients are roughly similar to the ones found in the literature based on individual level regressions and the ones found Hellerstein et al. (1999), based on a plant-level regression. For example, the coefficients on schooling are 0.078 and 0.086 for 1992 and 1982 respectively. These coefficients are slightly smaller — probably because of measurement error - but not completely different from the standard estimates of the private return to education obtained from worker-level data. ${ }^{35}$ Women and blacks are paid less, and older workers more. I conclude that the matched workerfirm sample contains some measurement error, but can roughly reproduce standard individual level wage equation results.

\footnotetext{
${ }^{34}$ Hellerstein et al. (1999) show that plant-level wage equations represent the aggregation of individual-level wage equations over workers employed in a plant and hence should provide coefficients similar to the ones obtained from their individual-level counterparts.

${ }^{35}$ One difference is that the 1992 estimates are usually found to be larger than the 1982 ones.
} 
Table 1: Summary Statistics

\begin{tabular}{lccccc}
\hline \hline & \multicolumn{2}{c}{1982} & & \multicolumn{2}{c}{1992} \\
\cline { 2 - 3 } \cline { 5 - 6 } & Mean & Std. Dev. & & Mean & Std. Dev. \\
& $(1)$ & $(2)$ & & $(3)$ & $(4)$ \\
\hline Value of Output (x 1000) & 19944.0 & 163592.5 & & 20938.7 & 174087.5 \\
Added Value (x 1000) & 8019.1 & 55307.8 & & 9412.53 & 69566.91 \\
Capital (x 1000) & 7042.1 & 62003.4 & & 8007.13 & 62502.58 \\
Hours Worked & 223.2 & 432.4 & & 222.7 & 435.7 \\
Hours worked by College Graduates & 38.9 & 309.5 & & 39.0 & 310.8 \\
Hours worked by Workers with Some College & 43.5 & 338.6 & & 67.7 & 333.7 \\
Hours worked by High School Graduates & 90.4 & 342.4 & & 73.7 & 310.0 \\
Hours worked by High School Drop Outs & 50.2 & 249.4 & & 42.4 & 136.8 \\
Hi Tech & 0.099 & 0.298 & & 0.099 & 0.298 \\
Average Hourly Wage & 13.54 & 5.50 & & 13.73 & 5.40 \\
Belong to Multi-Units Firm & 0.25 & 0.43 & & 0.29 & 0.45 \\
College Share Outside Industry & 0.147 & 0.042 & & 0.191 & 0.061 \\
Number of Plants & 40,281 & & & 40,281 & \\
\hline
\end{tabular}

NOTES: Monetary values are in 1992 dollars. 
Table 2: Estimates of Production Functions: Cross-Sectional Specification

\begin{tabular}{|c|c|c|c|c|}
\hline & \multicolumn{2}{|c|}{ Cobb-Douglas } & \multicolumn{2}{|c|}{$\overline{\text { Translog }}$} \\
\hline & $\begin{array}{c}1992 \\
(1)\end{array}$ & $\begin{array}{c}1982 \\
(2)\end{array}$ & $\begin{array}{c}1992 \\
(3)\end{array}$ & $\begin{array}{c}1982 \\
(4)\end{array}$ \\
\hline College Share in Other Industries & $\begin{array}{c}0.846 \\
(0.102)\end{array}$ & $\begin{array}{c}0.812 \\
(0.113)\end{array}$ & $\begin{array}{c}0.834 \\
(0.107)\end{array}$ & $\begin{array}{c}0.807 \\
(0.133)\end{array}$ \\
\hline ln Unskilled Labor & $\begin{array}{c}0.470 \\
(0.014)\end{array}$ & $\begin{array}{c}0.333 \\
(0.012)\end{array}$ & $\begin{array}{c}0.606 \\
(0.040)\end{array}$ & $\begin{array}{c}0.332 \\
(0.050)\end{array}$ \\
\hline ln Skilled Labor & $\begin{array}{c}0.382 \\
(0.015)\end{array}$ & $\begin{array}{c}0.196 \\
(0.010)\end{array}$ & $\begin{array}{c}0.465 \\
(0.039)\end{array}$ & $\begin{array}{c}0.265 \\
(0.060)\end{array}$ \\
\hline ln Capital & $\begin{array}{c}0.178 \\
(0.004)\end{array}$ & $\begin{array}{c}0.476 \\
(0.010)\end{array}$ & $\begin{array}{c}0.501 \\
(0.050)\end{array}$ & $\begin{array}{c}0.657 \\
(0.057)\end{array}$ \\
\hline ln Unskilled Labor sq. & & & $\begin{array}{c}0.098 \\
(0.011)\end{array}$ & $\begin{array}{c}0.096 \\
(0.010)\end{array}$ \\
\hline ln Skilled Labor sq. & & & $\begin{array}{c}0.068 \\
(0.011)\end{array}$ & $\begin{array}{c}0.053 \\
(0.012)\end{array}$ \\
\hline ln Capital sq. & & & $\begin{array}{c}0.048 \\
(0.002)\end{array}$ & $\begin{array}{c}0.024 \\
(0.002)\end{array}$ \\
\hline ln Unskilled $\times \ln$ Skilled & & & $\begin{array}{l}-0.111 \\
(0.018)\end{array}$ & $\begin{array}{l}-0.022 \\
(0.014)\end{array}$ \\
\hline ln Unskilled $\times \ln$ Capital & & & $\begin{array}{l}-0.075 \\
(0.010)\end{array}$ & $\begin{array}{l}-0.095 \\
(0.016)\end{array}$ \\
\hline ln Skilled $\times \ln$ Capital & & & $\begin{array}{l}-0.028 \\
(0.011)\end{array}$ & $\begin{array}{l}-0.047 \\
(0.016)\end{array}$ \\
\hline Multi-Unit & $\begin{array}{c}0.150 \\
(0.008)\end{array}$ & $\begin{array}{c}0.073 \\
(0.011)\end{array}$ & $\begin{array}{c}0.122 \\
(0.012)\end{array}$ & $\begin{array}{c}0.069 \\
(0.012)\end{array}$ \\
\hline $\begin{array}{l}\text { Industry Effects } \\
\text { R. sq. }\end{array}$ & $\begin{array}{l}\text { Yes } \\
0.89\end{array}$ & $\begin{array}{l}\text { Yes } \\
0.89\end{array}$ & $\begin{array}{l}\text { Yes } \\
0.91\end{array}$ & $\begin{array}{l}\text { Yes } \\
0.90\end{array}$ \\
\hline
\end{tabular}

Notes: Standard errors adjusted for clustering in parenthesis. Each column is a separate regression. All labor inputs are measured in number of hours worked. Industry effects are dummies for 3-digit industries. $N=40281$. See text for details. 


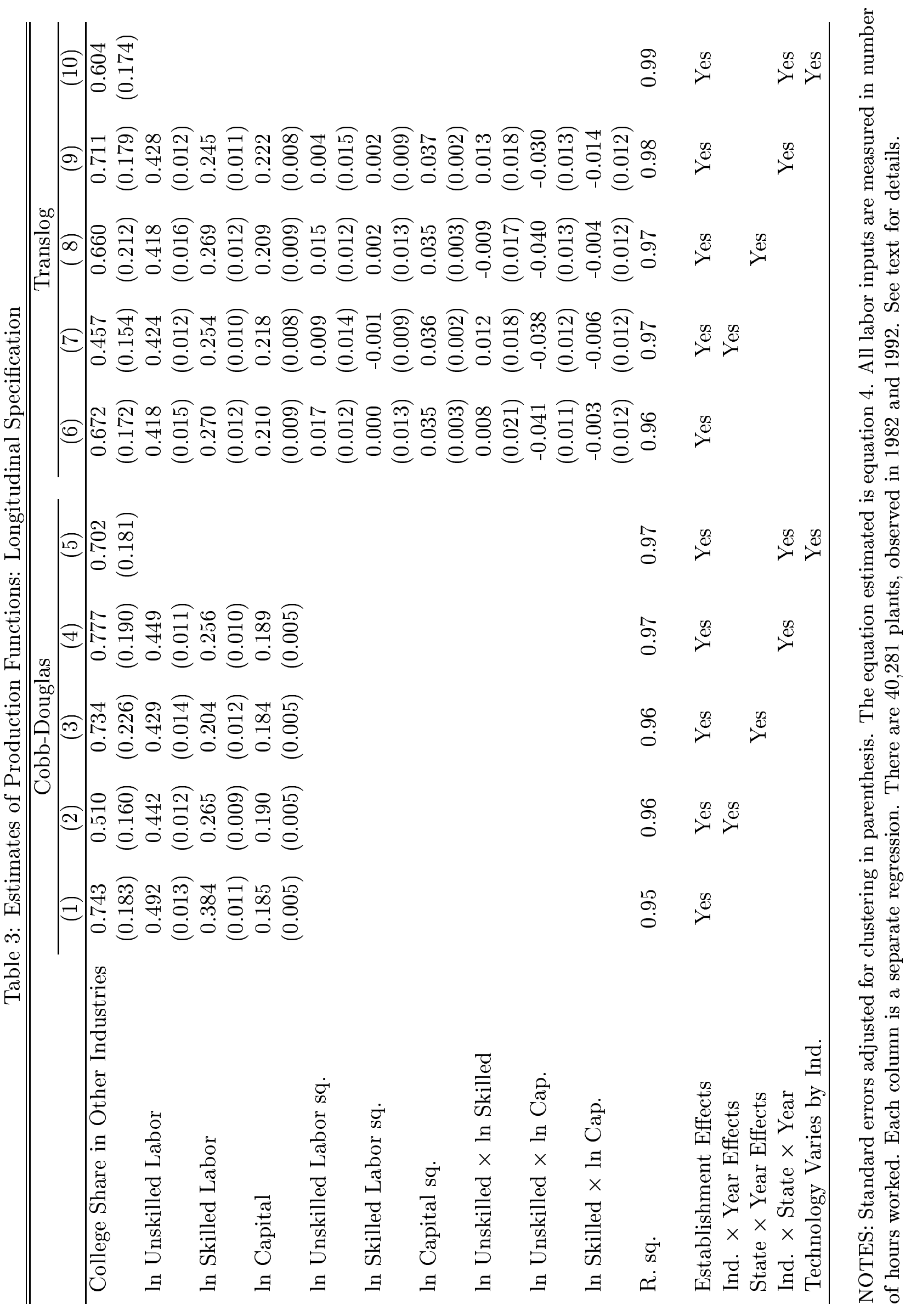


Table 4: The Effect of Physical Capital Outside the Plant on Plant Productivity

\begin{tabular}{|c|c|c|c|c|c|}
\hline & \multicolumn{2}{|c|}{ Cross-Section } & \multicolumn{3}{|c|}{ Panel } \\
\hline & \multirow{2}{*}{$\begin{array}{c}1982 \\
(1) \\
\end{array}$} & \multirow{2}{*}{$\begin{array}{c}1992 \\
(2) \\
\end{array}$} & & & \\
\hline & & & $(3)$ & $(4)$ & $(5)$ \\
\hline Model 1: & & & & & \\
\hline Coeff on ln Average Capital Outside Plant & $\begin{array}{c}0.349 \\
(0.067)\end{array}$ & $\begin{array}{l}-0.150 \\
(0.065)\end{array}$ & $\begin{array}{c}0.012 \\
(0.017)\end{array}$ & $\begin{array}{c}0.007 \\
(0.017)\end{array}$ & $\begin{array}{c}0.007 \\
(0.018)\end{array}$ \\
\hline Model 2: & & & & & \\
\hline Coeff on ln Average Capital Per Worker Outside Plant & $\begin{array}{c}1.871 \\
(0.661)\end{array}$ & $\begin{array}{l}-0.724 \\
(0.404)\end{array}$ & $\begin{array}{l}-0.005 \\
(0.021)\end{array}$ & $\begin{array}{l}-0.006 \\
(0.021)\end{array}$ & $\begin{array}{l}-0.004 \\
(0.022)\end{array}$ \\
\hline Establishment Effects & No & No & Yes & Yes & Yes \\
\hline State $\times$ Year Effects & No & No & No & Yes & No \\
\hline Industry $\times$ Year Effects & No & No & No & No & Yes \\
\hline
\end{tabular}

NOTES: Standard errors adjusted for clustering in parenthesis. Each entry is from a separate regression. The equation estimated is equation 4 , where human capital $\bar{S}$ is substituted with a measure of physical capital. Entries in row 1 are the coefficients on the log of average physical capital outside the plant in a city. Entries in row 2, are the coefficients on the log of per worker average physical capital outside the plant in the city. All models control for capital in the plant, and hours worked by skilled and unskilled workers in the plant. There are 40,281 plants, observed in 1982 and 1992 . See text for details. 
Table 5: The Spillover Effect of College Share in all 1-Digit Industries on Productivity in Manufacturing, by Economic Distance from Manufacturing

\begin{tabular}{lccc}
\hline \hline & $\begin{array}{c}\text { Coefficient on } \\
\text { College Share } \\
\text { in Specified Industry }\end{array}$ & $\begin{array}{c}\text { Inputs in Manuf. } \\
\text { (Billions of Dollars) }\end{array}$ & $\begin{array}{c}\text { Distance } \\
\text { (Rank) }\end{array}$ \\
\hline Manufacturing & 0.802 & 841 & 1 \\
Transportation, Communication, Utilities & $(192)$ & 122 & 2 \\
& 0.488 & 119 & 3 \\
Trade & $(0.213)$ & & \\
& 0.705 & 112 & 4 \\
Services & $(0.335)$ & 93 & 5 \\
Mining & 0.213 & & \\
& $(0.284)$ & 29 & 6 \\
Finance & -0.004 & 14 & 7 \\
Construction & $(0.042)$ & & \\
& 0.048 & & \\
\hline
\end{tabular}

NOTES: Standard errors adjusted for clustering in parenthesis. The equation estimated is equation 5. Entries in column 1 are the $\gamma_{k}$ coefficients in equation 5 , where $k$ indexes 1-digit industries. The model controls for capital, hours worked by skilled and unskilled workers, establishment effects, industry $\times$ year and state $\times$ years effects. Column 2 reports the value of inputs from each industry used in manufacturing. The value of input is a measure of economic distance. There are 40,281 plants, observed in 1982 and 1992. See text for details. 
Table 6: The Spillover Effect of College Share in all 2-Digit Industries on Productivity in Manufacturing, by Economic Distance from Manufacturing

\begin{tabular}{cc}
\hline \hline $\begin{array}{c}\text { Distance } \\
(\text { Rank })\end{array}$ & Coeff on College Share \\
$(1)$ & in Specified Group of Industries \\
\hline $1-5$ & 0.577 \\
& $(0.187)$ \\
$6-10$ & 0.314 \\
& $(0.233)$ \\
$11-15$ & 0.413 \\
& $(0.182)$ \\
$16-20$ & 0.230 \\
& $(0.186)$ \\
$21-25$ & 0.232 \\
& $(0.161)$ \\
$26-30$ & 0.076 \\
& $(0.119)$ \\
$30+$ & 0.083 \\
& $(0.074)$ \\
\hline
\end{tabular}

NOTES: Standard errors adjusted for clustering in parenthesis. The equation estimated is equation 5. Column 1 reports the rank based on economic distance between the relevant 2-digit industries. Entries in column 2 are the $\gamma_{k}$ coefficients in equation 5, where $\mathrm{k}$ indexes 2-digit industries. For example, the entry in row 1 is the coefficient on college share in the 5 2-digit industries that are closest to the relevant plant. The model controls for capital, hours worked by skilled and unskilled workers, establishment effects, industry $\times$ year and state $\times$ years effects. There are 40,281 plants, observed in 1982 and 1992. See text for details. 


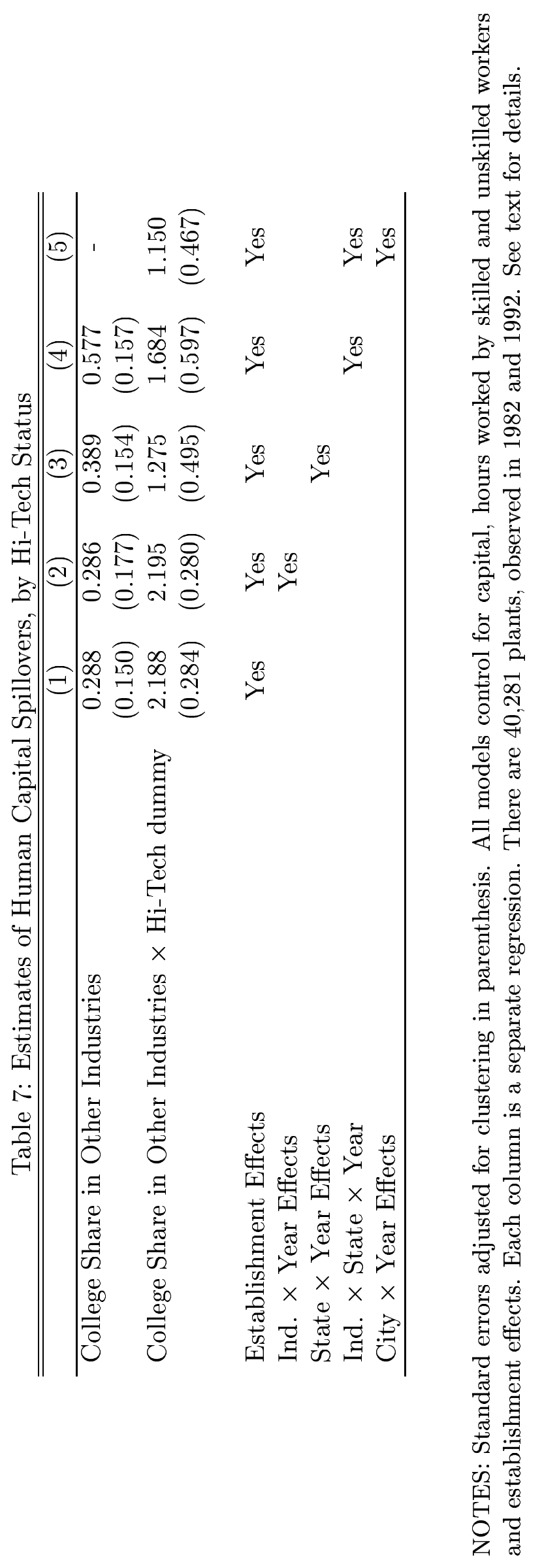


Table 8: Estimates of Human Capital Spillovers, by Fraction of Non-Production Workers in the Plant and by Fraction of College Educated Workers in the Plant

\begin{tabular}{ccc}
\hline \hline Specification 1: & Fraction of Non-Production & Coefficient on \\
Workers in the Plant & $(1)$ & College Share in \\
Other Industries & $(2)$ \\
\cline { 2 - 3 } & $0 \%-33 \%$ & 0.478 \\
$34 \%-66 \%$ & $(0.170)$ \\
& 0.871 \\
$67 \%-100 \%$ & $(0.185)$ \\
& 1.766 \\
& $(0.488)$ \\
\hline Specification 2: & Fraction of Skilled Workers & Coefficient on \\
in the Plant & College Share in \\
& Other Industries \\
& $(1)$ & $(2)$ \\
\cline { 2 - 3 } & 0.402 & $(0.259)$ \\
& & 0.475 \\
$34 \%-66 \%$ & $(0.142)$ \\
& 2.687 \\
& & $(0.231)$ \\
\hline
\end{tabular}

NOTES: Standard errors adjusted for clustering in parenthesis. Column 1 indicates the fraction of non-production workers to total workers in plant (upper panel) and the fraction of college educated workers to total workers in plant (lower panel). Each panel is a separate regression. Both models control for capital, hours worked by skilled and unskilled workers, establishment effects, industry $\times$ year and state $\times$ years effects. There are 40,281 plants, observed in 1982 and 1992. See text for details. 


\begin{tabular}{ccc} 
Table 9: Estimates of Human Capital Spillovers, by Multi-Unit Status \\
\hline \hline & Single Unit & Multi Unit \\
& Plants & Plants \\
\cline { 2 - 3 } & $(1)$ & $(2)$ \\
\hline College Share in Other Industries & 0.910 & 0.419 \\
& $(0.170)$ & $(0.321)$ \\
$\mathrm{N}$ & 30,211 & 10,070 \\
\hline
\end{tabular}

NOTES: Standard errors adjusted for clustering in parenthesis. Multi-unit status indicates whether a plant belongs to a firm with more than one establishment. Each entry is a separate regression. Both models control for capital, hours worked by skilled and unskilled workers, establishment effects, industry $\times$ year and state $\times$ years effects. See text for details. 
Table 10: Robustness Checks

\begin{tabular}{lc}
\hline \hline & $\begin{array}{c}\text { Coeff on College Share } \\
\text { in Other Industries }\end{array}$ \\
\hline (1) Base Specification & 0.743 \\
& $(0.183)$ \\
(2) Shipments & 0.866 \\
& $0.198)$ \\
(3) Weighted regression & 0.694 \\
& $(0.202)$ \\
(4) Small plants (1-10 workers) & 0.692 \\
& $(0.259)$ \\
(5) Medium plants (11-50 workers) & 0.816 \\
& $(0.206)$ \\
(6) Large plants (51+ workers) & 0.755 \\
& $0.319)$ \\
(7) Three education groups & 0.684 \\
& $(0.195)$ \\
(8) Four education groups & 0.523 \\
& $(0.202)$ \\
(9) Production, non production workers & 0.489 \\
& $(0.143)$ \\
(10) Coeff on labor inputs vary across cities, time & 0.501 \\
& $(0.202)$ \\
(11) City population & 0.742 \\
& $(0.183)$ \\
(12) City pop. + other city characteristics & 0.703 \\
& $(0.188)$ \\
\hline
\end{tabular}

NOTES: Standard errors adjusted for clustering in parenthesis. Each entry is a separate regression.

(1) The base case is from Table 3, column 1.

(2) The dependent variable is value of shipments.

(3) Weights are based on the distribution of plant size in the 1982 population.

(4) Sample includes only plants with 10 workers or less.

(5) Sample includes only plants with 11-50 workers.

(6) Sample includes only plants with more than 50 workers.

(7) Model controls for hours worked by 3 education groups(high school or less, some college and college).

(8) Model controls for hours worked by 4 education groups (less than high school, high school, some college and college).

(9) Model controls for hours worked by production and non production workers.

(10) The coefficient on skilled and unskilled labor can vary across cities and over time.

(11) Model controls for city population.

(12) Model controls for city population and other city characteristics. 
告
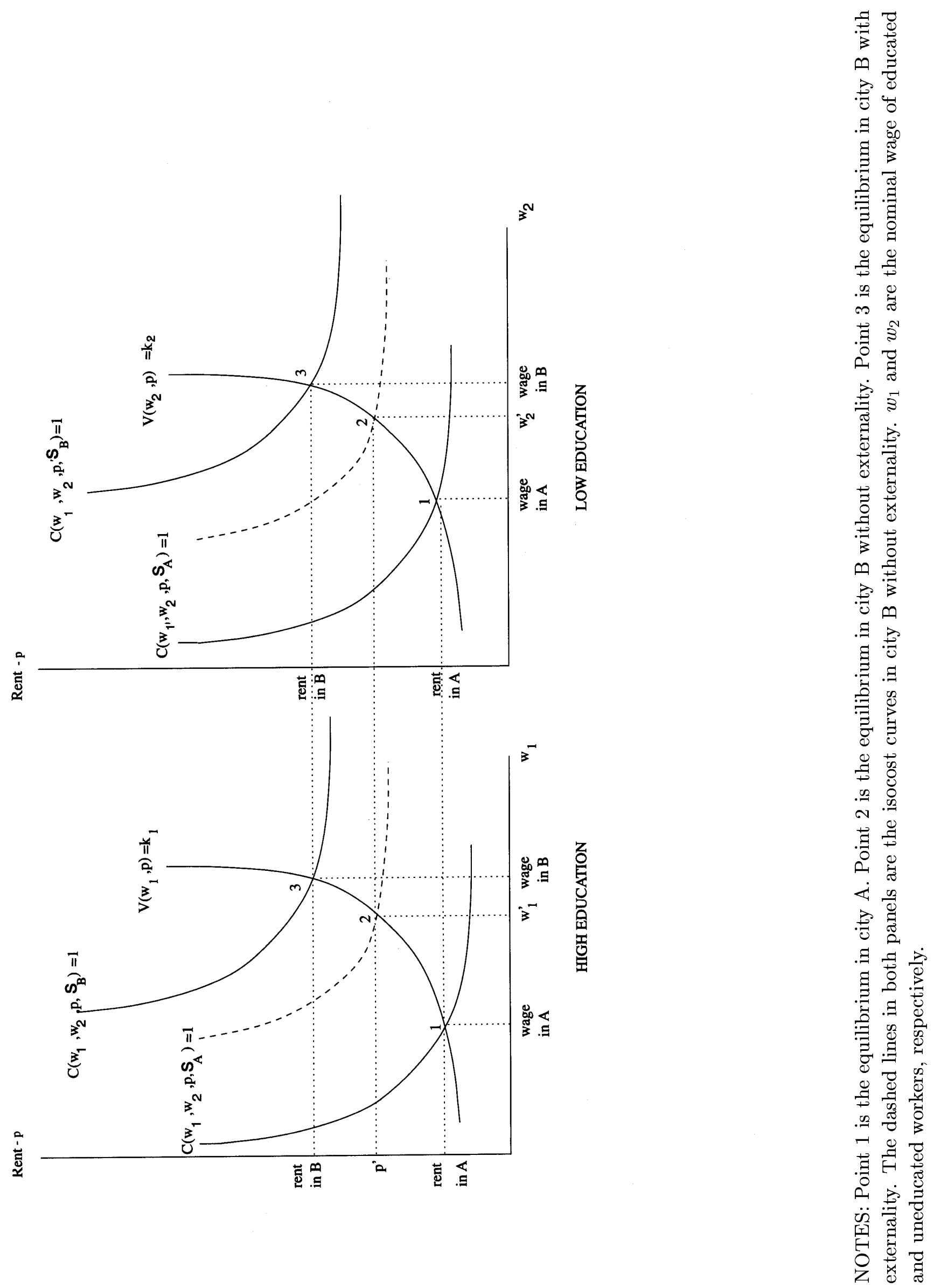
Figure 2: The Spillover Effect of College Share in all 1-Digit Industries on Productivity in Manufacturing, by Economic Distance from Manufacturing

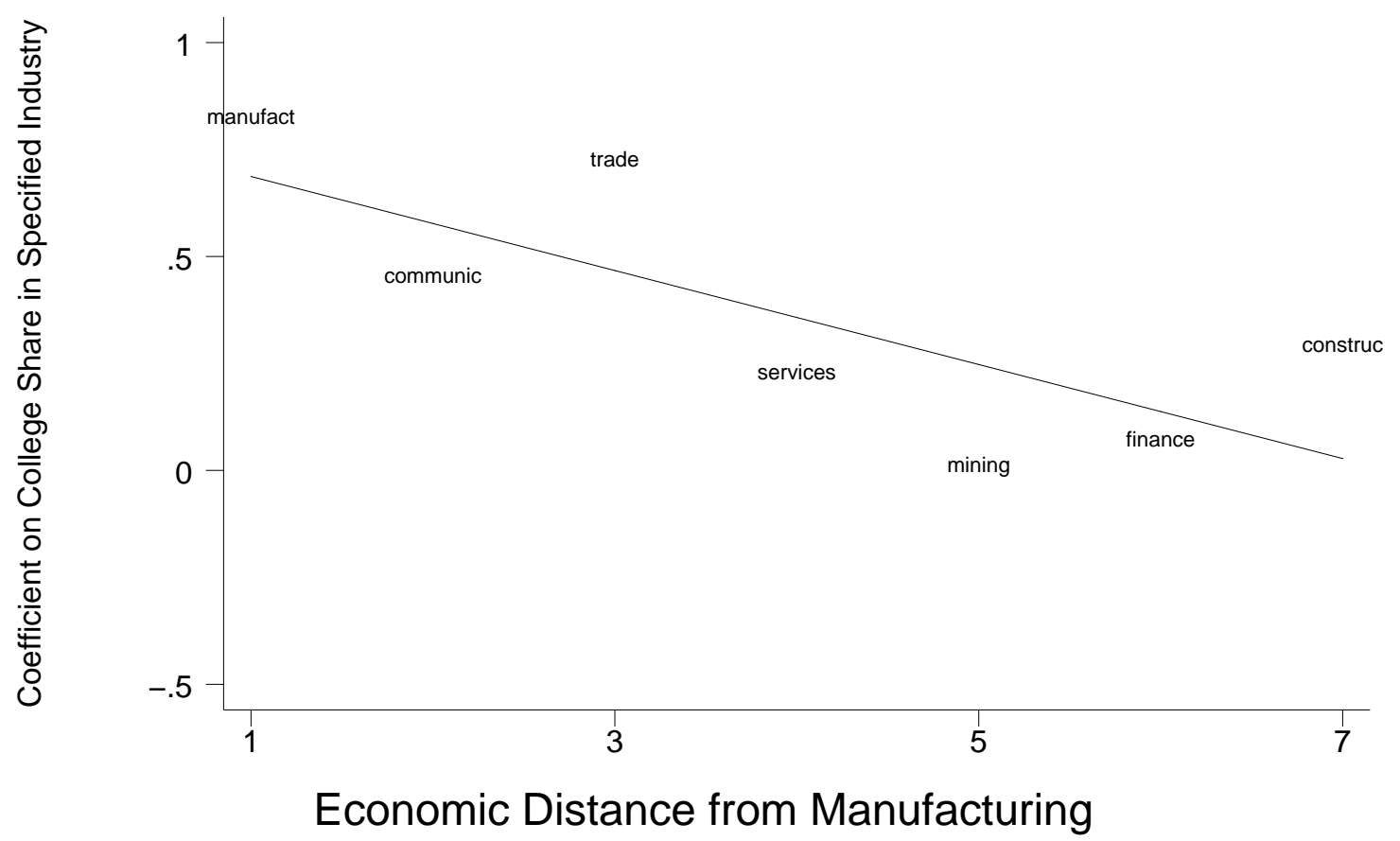

Notes: The figure plots the estimated coefficients on college share in each industry (from Table 5 , column 1) on the y-axis against the rank in value of inputs, on the x-axis (from Table 5, column 3). For example, manufacturing has rank 1, because the value of inputs is highest for manufacturing. Transportation has rank 2, trade has rank 3, etc. The OLS fitted line is superimposed. The slope (standard error) of the line is -0.109 (0.042). See text for details. 
Figure 3: The Spillover Effect of College Share in all 2-Digit Industries on Productivity in Manufacturing, by Economic Distance from Manufacturing

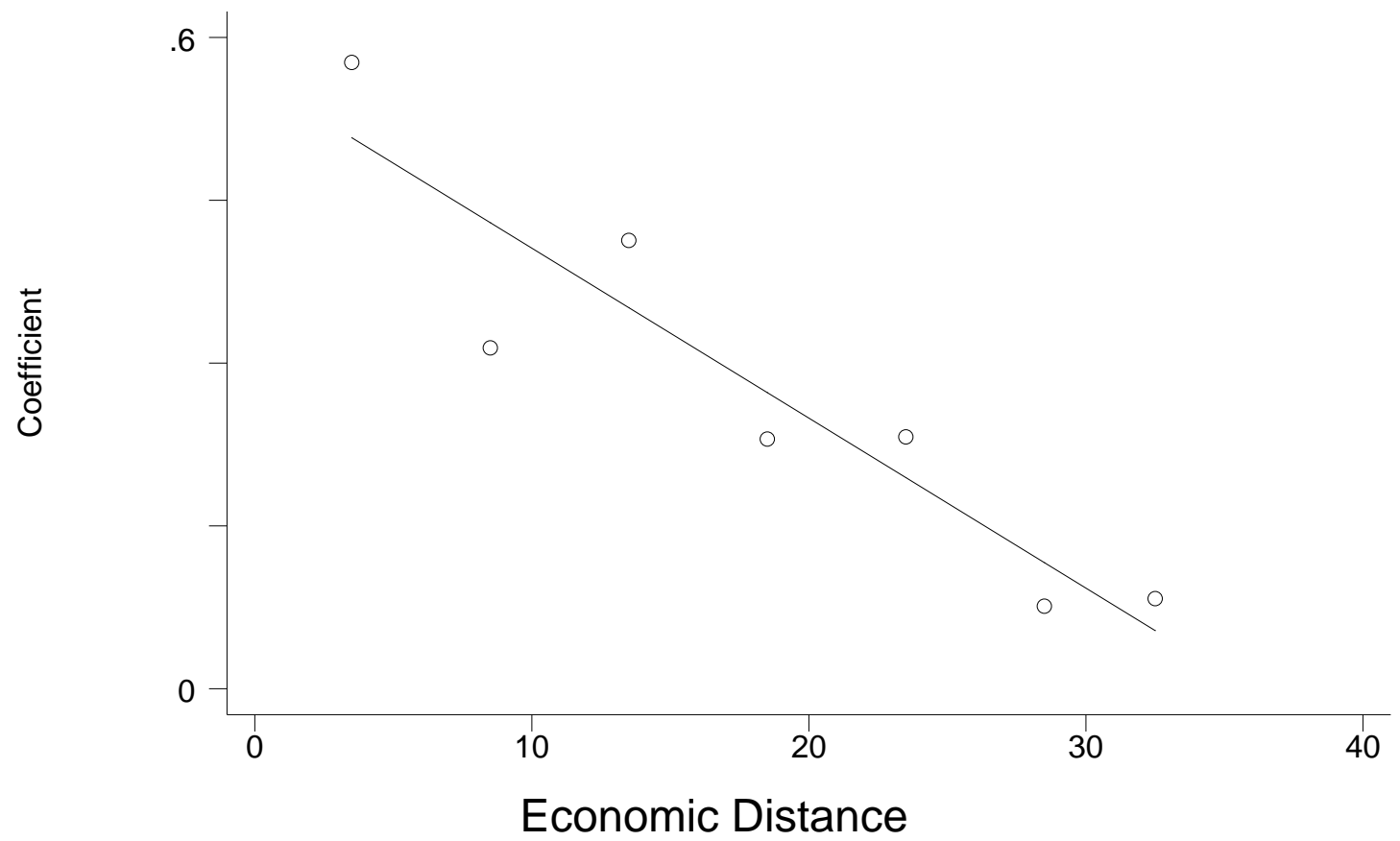

Notes: The figure plots the estimated coefficients on college share in each industry group (from Table 6, column 1) on the y-axis against the rank in value of inputs, on the x-axis (from Table 6 , column 2). The OLS fitted line is superimposed. The slope (standard error) of the line is -0.015 (0.002). See text for details. 
Table A1: Plant-Level Wage Equations

\begin{tabular}{lcc}
\hline \hline & 1992 & 1982 \\
& $(1)$ & $(2)$ \\
\hline Schooling & 0.078 & 0.086 \\
& $(0.004)$ & $(0.006)$ \\
Percentage Female & -0.304 & -0.449 \\
& $(0.029)$ & $(0.026)$ \\
Percentage Black & -0.123 & -0.026 \\
& $(0.056)$ & $(0.058)$ \\
Average Age & 0.011 & 0.012 \\
& $(0.001)$ & $(0.001)$ \\
City Effects & & \\
R. sq. & Yes & Yes \\
\hline & 8.8 & 8.3 \\
\hline
\end{tabular}

NOTES: Standard errors adjusted for clustering in parenthesis. The dependent variable is log of average wage in the plant. Data on wages, from the Census of Manufacturers, are plant averages obtained by dividing the total wage bill by the number of hours worked. Data on workers are cell averages from the Census of Population. For example, "percentage female" is the fraction of women in the industry and city to which the plant belongs. There are 40,281 plants, observed in 1982 and 1992. See text for details. 